University of Nebraska - Lincoln

DigitalCommons@University of Nebraska - Lincoln

1995

\title{
Recent state of stress change in the Walker Lane zone, western Basin and Range province, United States
}

Oliver Bellier

Centre National de la Recherche Scientifique

Mary Lou Zoback

U.S. Geological Survey, marylouz@stanford.edu

Follow this and additional works at: https://digitalcommons.unl.edu/usgsstaffpub

Part of the Earth Sciences Commons

Bellier, Oliver and Zoback, Mary Lou, "Recent state of stress change in the Walker Lane zone, western Basin and Range province, United States" (1995). USGS Staff -- Published Research. 472.

https://digitalcommons.unl.edu/usgsstaffpub/472

This Article is brought to you for free and open access by the US Geological Survey at DigitalCommons@University of Nebraska - Lincoln. It has been accepted for inclusion in USGS Staff -- Published Research by an authorized administrator of DigitalCommons@University of Nebraska - Lincoln. 


\title{
Recent state of stress change in the Walker Lane zone, western Basin and Range province, United States
}

\author{
Olivier Bellier \\ Centre National de la Recherche Scientifique, URA D1369, Université de Paris-Sud, Orsay Cedex
}

Mary Lou Zoback

U.S. Geological Survey, Menlo Park, California

Abstract. The NW to north-trending Walker Lane zone (WLZ) is located along the western boundary of the northern Basin and Range province with the Sierra Nevada. This zone is distinguished from the surrounding Basin and Range province on the basis of irregular topography and evidence for both normal and strike-slip Holocene faulting. Inversion of slip vectors from active faults, historic fault offsets, and earthquake focal mechanisms indicate two distinct Quaternary stress regimes within the WLZ, both of which are characterized by a consistent WNW $\sigma_{3}$ axis; these are a normal faulting regime with a mean $\sigma_{3}$ axis of $N 85^{\circ} \pm 9^{\circ} \mathrm{W}$ and a mean stress ratio ( $R$ value) $\left(R=\left(\sigma_{2}-\sigma_{1}\right) /\left(\sigma_{3}-\sigma_{1}\right)\right)$ of $0.63-0.74$ and a younger strike-slip faulting regime with a similar mean $\sigma_{3}$ axis $\left(\mathrm{N}^{\circ} 5^{\circ}\right.$ $70^{\circ} \mathrm{W}$ ) and $R$ values ranging between $\sim 0.1$ and 0.2 . This younger regime is compatible with historic fault offsets and earthquake focal mechanisms. Both the extensional and strikeslip stress regimes reactivated inherited Mesozoic and Cenozoic structures and also produced new faults. The presentday strike-slip stress regime has produced strike-slip, normal oblique-slip, and normal dip-slip historic faulting. Previous workers have explained the complex interaction of active strike-slip, oblique, and normal faulting in the WLZ as a simple consequence of a single stress state with a consistent WNW $\sigma_{3}$ axis and transitional between strike-slip and normal faulting (maximum horizontal stress approximately equal to vertical stress, or $R \approx 0$ in both regimes) with minor local fluctuations. The slip data reported here support previous results from Owens Valley that suggest deformation within temporally distinct normal and strike-slip faulting stress regimes with a roughly constant WNW trending $\sigma_{3}$ axis (Zoback, 1989). A recent change from a normal faulting to a strike-slip faulting stress regime is indicated by the crosscutting striae on faults in basalts $<300,000$ years old and is consistent with the dominantly strike-slip earthquake focal mechanisms and the youngest striae observed on faults in Plio-Quaternary deposits. Geologic control on the timing of the change is poor; it is impossible to determine if there has been a single recent absolute change or if there is, rather, an alternating or cyclical variation in stress magnitudes. Our slip data, in particular, the cross-cutting normal and strike-slip striae on the same fault plane, are inconsistent with postulated

Copyright 1995 by the American Geophysical Union.

Paper number 94TC00596.

0278-7407/95/94TC-00596\$10.00 simple strain partitioning of deformation within a single regional stress field suggested for the WLZ by Wesnousky and Jones [1994]. The location of the WLZ between the deepseated regional extension of the Basin and Range and the right-lateral strike-slip regional tectonics of the San Andreas fault zone is probably responsible for the complex interaction of tectonic regimes in this transition zone. In early to midTertiary time the WLZ appears to have had a similarly complex deformational history, in this case as a back arc or intra-arc region, accommodating at least part of the right-lateral component of oblique convergence as well as a component of extension.

\section{Introduction}

The Walker Lane belt or zone (WLZ), as defined by Stewart [1988], is a NW to north trending structural zone, $\sim 700 \mathrm{~km}$ long and $200-300 \mathrm{~km}$ wide, located in the westernmost part of the Northern Basin and Range province. This zone is characterized by rather irregularly-shaped topography, in contrast to the linear ranges and basins to the east (Figures 1 and 2), and has had a complex structural and tectonic evolution [Stewart, 1988, 1992; Bellier and Zoback, 1991]. Deformation within the zone was initiated during Late Triassic or Jurassic time, probably in response to oblique subduction which produced a broad right-lateral strike-slip fault zone along the magmatic arc and within the back arc region [Stewart, 1988, 1992]. Cenozoic deformation styles within the WLZ include both strike-slip fault zones and a range of extensional features including detachment faults and core complexes (in highly extended areas) as well as normal to oblique normal faulting associated with both symmetric and asymmetric basin-range blocks [e.g., Thompson and Burke, 1973; Proffett, 1977; Stewart, 1978, 1979, 1983, 1988, 1992; Zoback et al., 1981; Hardyman, 1984; Wallace, 1984a,b; Beanland and Clark, 1995].

The study area for the current investigation is shown in Figure 1 and lies within the WLZ and adjacent regions of the western Basin and Range and includes sites along the Sierra Nevada frontal fault zone on the west and the north trending Nevada Seismic Belt on the east [e.g., Slemmons et al., 1979; Stewart, 1988, 1992] (note that this seismic belt is not limited to Nevada but extends southward into easternmost California and includes Owens Valley). The results reported here are a subset of a broader study of stress state in this region reported by Bellier and Zoback [1991] which demonstrated two phases of late Tertiary normal faulting regime within the WLZ 


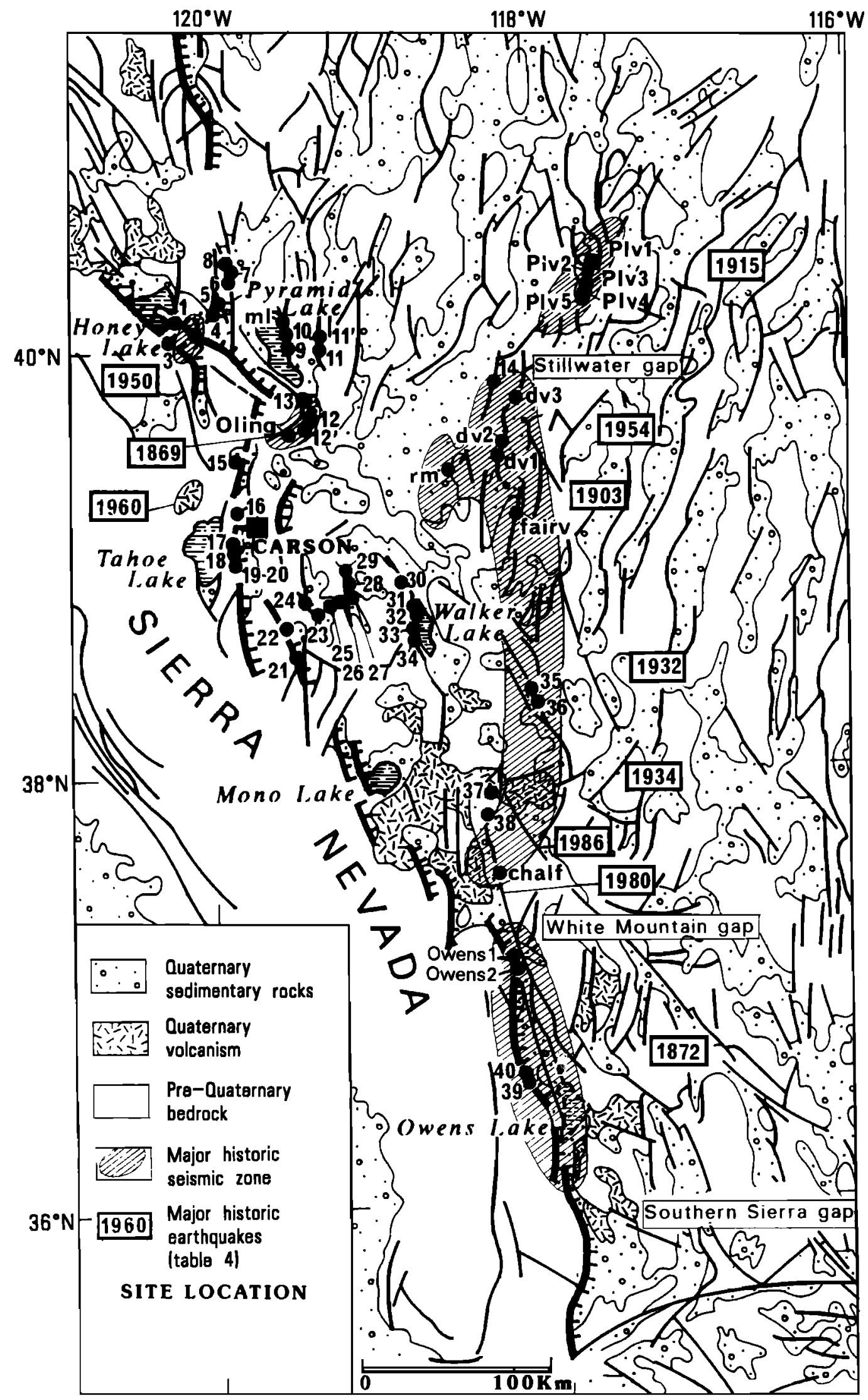


as follows: an older phase characterized by NE to ENE trending extension directions (believed to correspond to a regionally defined "pre-basin-range" extensional phase [Zoback et al., 1981]) and a younger deformational phase corresponding with WNW trending "modern" basin-range extension [Zoback and Zoback, 1980, 1989; Stock et al., 1985; Zoback, 1989]. This $\sim 40^{\circ}$ clockwise change in the $\sigma_{3}$ stress direction was previously recognized elsewhere in the Northern Basin and Range province and is believed to have occurred between 10 and 7 m.y.B.P. in response to superimposed shear related to development of the San Andreas transform system [Zoback and Thompson, 1978; Eaton et al., 1978; Eaton, 1979; Zoback et al., 1981]. Thus the WLZ shows an extensional deformational history similar to the rest of the Northern Basin and Range; however, within the WLZ the extensional deformation apparently preceded a complex early Tertiary deformational episode characterized by a strike-slip to oblique-reverse tectonism [Bellier and Zoback, 1991].

Both geologic and earthquake focal mechanism data indicate an abundance of strike-slip faulting in addition to normal faulting within the WLZ. Many of these strike-slip faults have been active during late Tertiary and into recent time [e.g., dePolo et al., 1989, 1991; Wallace, 1979, 1987; Bell, 1981, 1984a,b; Bell et al., 1984; Doser, 1988, Beanland and Clark, 1995]. A detailed field investigation of scarps formed in the 1872 ( $M$ 7.6 \pm 4 ) Owens Valley earthquake established the dominantly strike-slip character of that particular fault zone as well as provided evidence for at least three large Holocene strike-slip events along the zone [Beanland and Clark, 1995]. The Owens Valley fault zone is subparallel to the adjacent dominantly normal Sierran frontal fault zone which, in this area, has demonstrated late Quaternary displacement but no resolvable Holocene movement [Gillespie, 1982]. Previously, Wright [1976] suggested that the complex interaction of active strike-slip, oblique, and normal faulting in the WLZ was a simple consequence of a single stress state with a consistent WNW $\sigma_{3}$ axis and transitional between strike-slip and normal faulting (maximum horizontal stress $\sigma_{H \max } \approx$ vertical stress $\left.\sigma_{V}\right)$ with minor local fluctuations. However, Zoback [1989] showed that the large difference in rake of slip vectors on these two subparallel faults can not be explained by a single stress state with $\sigma_{H \max } \approx \sigma_{V}$, and suggested a recent (post100,000 to pre-10,000 years) major temporal variation in stress regime.

Alternately, Wesnousky and Jones [1994] have suggested that the contrast in rake angles of slip on subparallel faults both in the Owens Valley region and throughout the Walker Lane is an example of "strain partitioning," a deformation style analogous to the contemporaneous strike-slip and thrust deformation on subparallel faults within the San Andreas fault system in California. Extensive study of the state of stress adjacent to the San Andreas indicates that this strain partitioning is the consequence of deformation within a single regional stress field, one in which the maximum horizontal stress is oriented roughly $80-85^{\circ}$ clockwise to the strike of the San Andreas fault and in which the major strike-slip fault (the San Andreas proper) has a shear strength substantially lower than the surrounding faults and crust [Mount and Suppe, 1987; Zoback et al., 1987; Oppenheimer et al., 1988].

The focus of the current study is fourfold; (1) to determine the Quaternary to present-day state of stress acting in the WLZ by inversion of both geologically and seismically determined slip vectors on minor and major faults within the zone, (2) to test whether observed slip vectors can be explained by a single, transitional stress state, (3) to analyze implications of crosscutting sets of late Cenozoic fault striae with rake angles which differ by more than $60^{\circ}$ for possible temporal variations in stress regime, and (4) to examine the hypothesis of strain partitioning in light of the temporal faulting relationships and slip compatibility within a uniform regional stress field.

\section{Inversion of Fault Slip Data to Determine Stress State}

Kinematics of a fault population can be defined using the striations observed on the fault planes. Often, however, more than one set of striae are present on a fault plane. Separation of distinct families of striations must be done on the basis of geological field data using relative chronology of the striations (crosscutting relationships) and their relationship with regional tectonic events. The initial analysis of the slip data presented here was conducted using graphical methods [e.g., Vergely et al., 1987] to distinguish, when necessary, distinct families of striations at individual sites. The methodology of kinematic analysis of fault slip data used here to define stress state has been developed over the past 20 years by French structural geologists [e.g., Carey, 1979; Carey and Brunier, 1974, Angelier, 1979, 1984]. This form of analysis has been applied to constrain temporal and spatial changes in the stress state in numerous regions such as in the Central Andes [e.g., Sébrier et al., 1988; Bellier et al., 1991; Mercier et al., 1992].

If one assumes that the slip vectors indicated by the striations represent the direction of the maximum resolved shear stress on each fault plane [e.g., Bott, 1959], then the observations of fault slip on multiple planes can be inverted to determine a mean best fitting stress tensor. To determine the stress state responsible for late Cenozoic faulting in the WLZ, we performed such a quantitative inversion of families of slip data, determined at individual sites, using a method

Figure 1. Simplified geological map of the Walker Lane zone with locations of fault slip measurement sites indicated by solid circles and identified by numbers (or letters for sites located along known historic active fault zones). Main Sierra Nevada eastern bounding fault zone is indicated by a thick, solid line, hachured on the down-thrown side. Major basins are indicated by stippling and the main range-bounding faults are schematically indicated. The Nevada Seismic Belt (which extends into easternmost California) is shown by the diagonally lined area, and the date and approximate locations of the major historic earthquakes within this belt are shown by the year in rectangles. 


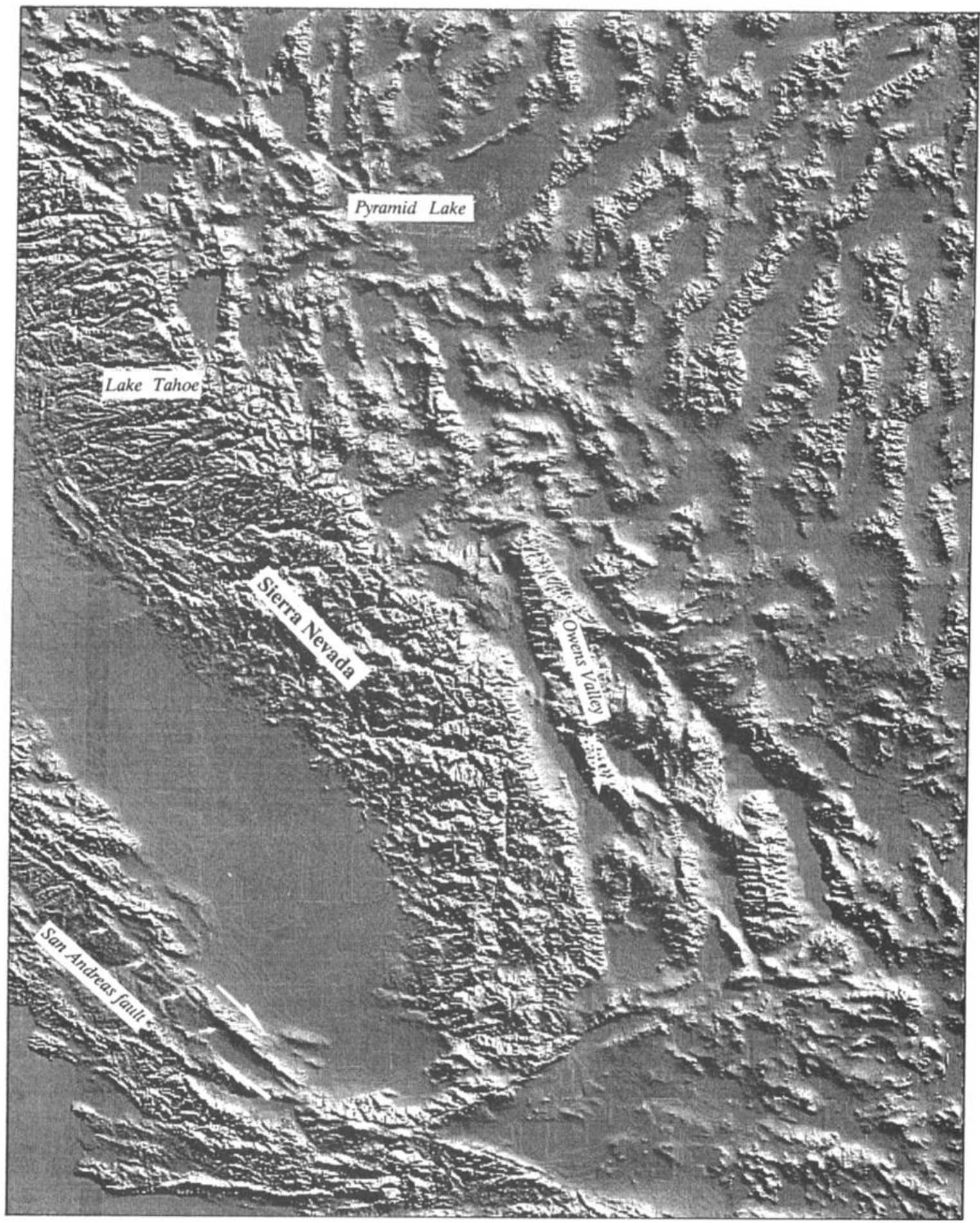

Figure 2. Digitally shaded relief map of the Walker Lane zone and westernmost Basin and Range with several localities noted.

originally proposed by Carey [1979]. This fault slip inversion method computes a mean best fitting deviatoric stress tensor from a set of striated faults by minimizing the angular deviation between a predicted slip vector $\tau$ and the observed striation s [Carey, 1979; Carey and Brunier, 1974]. The inversion results include the orientation (azimuth and plunge) of the principal stress axes $\sigma_{1}>\sigma_{2}>\sigma_{3}$ of a mean deviatoric stress tensor as well as a "stress ratio" $R=\left(\sigma_{2}-\sigma_{1}\right) /\left(\sigma_{3}-\sigma_{1}\right)$, a linear quantity describing relative stress magnitudes. It should be noted that $R=1-\phi, \phi$ being another commonly used stress ratio [e.g., Angelier, 1984; Zoback, 1989]. Discussion of the significance of stress ratio variations in interpreting 
inversions results is presented in a recent paper by Ritz and Taboada [1993].

As defined, the stress ratio $R$ varies between two endmember uniaxial stress states $\left(R=0\right.$ when $\sigma_{2}=\sigma_{1}$, and $R=1$ when $\sigma_{2}=\sigma_{3}$ ). In a normal faulting stress regime (where vertical stress $\sigma_{V}=\sigma_{1}$, and maximum horizontal stress $\sigma_{\text {Hmax }}=\sigma_{2}$ ) an $R=1$ indicates that the two horizontal stresses are equal (radial extension) and the predicted deformation is pure normal (downdip) slip on dipping faults of all orientations. In a strike-slip faulting stress regime $\left(\sigma_{V}=\sigma_{2}\right.$ and $\left.\sigma_{H \max }=\sigma_{1}\right)$ the $R=1$ end-member represents a stress state transitional to thrust faulting (in which minimum horizontal stress, $\sigma_{h \min }=$ $\left.\sigma_{V}\right)$. In contrast, $R=0\left(\sigma_{2}=\sigma_{1}\right)$ in either a normal faulting or strike-slip faulting stress regime indicates that the maximum horizontal and vertical stresses are equal $\left(\sigma_{H \max }=\sigma_{V}\right)$, implying a stress state transitional between strike-slip and normal faulting. Near-transitional strike-slip or normal faulting stress states require only minor fluctuation of stress magnitudes to go from one stress regime to the other. The predicted deformation for the transitional or near-transitional stress states $(R<0.15$ in either a normal or strike-slip faulting stress regime) can range between oblique-normal faulting to pure strike-slip faulting, depending on the orientation of the fault.

Results of stress inversions are generally considered reliable if $80 \%$ of the deviation angles (angle between the calculated slipvector $\tau$ and the observed striation $s$ ) are less than $20^{\circ}$ and if the computed solution is stable (i.e., the inversion tends toward the same solution regardless of the initial given parameter values). However, in our study we have established specific criteria for distinguishing wellconstrained inversion solutions (Table 1). The objective, quantitative part of the quality assessment is based on the value of the mean deviation angle and its standard deviation. Equally important, but more subjective, parameters influencing the quality include the number of fault planes sampled and the distribution of their attitudes. All fault slip inversion schemes are based on the assumption that the measured slip direction on each plane represents the direction of the maximum resolved shear stress on that plane. In this case there are four unknowns (three defining the orientation of the principal axes and one defining the stress ratio $R$ ), and any inversion thus requires at least four independent fault sets. Ideal data sets contain faults dipping in both directions with distinct strike directions, not just a continuum of strikes around a single mean direction.

We have adopted an alternate approach to deal with poorly distributed fault sets, utilizing a "fixed" inversion, i.e., one in which the principal stress axes are fixed to lie in horizontal and vertical planes (considered generally to be the case in the Earth's crust [see Zoback and Zoback, 1980] and consistent with results from most of the well-distributed data sets in this paper.). In this fixed inversion there are only two unknowns (the orientation of one of the horizontal stresses and the stress ratio), thus requiring only two independent fault sets. As discussed below, the inferred horizontal stress orientations from the fixed inversion are typically within $5-10^{\circ}$ of the stress axes obtained from standard inversions of data sets which lack the fault distributions to define four independent fault sets.
Table 1. Specific Criteria for Distinguishing WellConstrained Inversion Solutions

\begin{tabular}{lc}
\hline \multicolumn{1}{c}{ Criteria } & Value \\
\hline $\mathrm{N}$, number of faults & $\mathrm{N}>11$ \\
M.D., mean deviation angle & M.D. $<13^{\circ}$ \\
{$[\Sigma(\tau, s)] / \mathrm{N}$} & \\
where $(\tau, s)$ is angle between \\
the predicted $(\tau)$ and \\
observed $s$ slip vectors \\
$\begin{array}{c}\text { S.D., standard deviation } \\
{\left[\left(\Sigma(\tau, s)^{2}\right) / \mathrm{N}\right]^{1 / 2}}\end{array}$ \\
$\begin{array}{c}\text { Plunge of subvertical stress } \\
\text { axes }\end{array}$ \\
$\begin{array}{c}\text { Plunge of minimum } \\
\text { "horizontal" stress }\end{array}$ \\
$\begin{array}{c}\text { Plunge of maximum } \\
\text { "horizontal" stress }\end{array}$ \\
\hline
\end{tabular}

\section{Results}

Sites of fault slip measurements in this study are shown in Figure 1, and the locations of each site and the age of the faulted formations in which striae are measured are given in Table 2. Detailed locations for a number of important fault slip localities are given in the appendix. As mentioned previously, the focus of this paper is the Quaternary to present-day state of stress in the WLZ. Unfortunately, it is generally difficult to date the age of fault striations any more precisely than being younger than the age of the rocks cut by the faults. In this study we have included results of measurements made in Mesozoic to Plio-Quaternary age rocks. The inversion results from the youngest striae affecting the Mesozoic and early Tertiary rocks generally agree with the results from the relatively few striations on faults affecting the PlioQuaternary deposits.

As shown in Figure 3, normal slip striations were found to be crosscut by right-lateral shallow rake striations along the same major fault planes or adjacent faults at two localities along the southern segment of the Nevada Seismic Belt, along the Owens Valley and Rainbow Mountain fault zones (localities owens2 and rm in Figure 1). In Owens Valley these two contrasting sets of striae are observed on a fault zone parallel to and directly west $(<1 \mathrm{~km})$ of the main Owens Valley fault zone (Figure 4). Both faults cut late Pleistocene basalt from Crater Mountain dated at $288 \pm 70 \mathrm{ka}$ [Turrin and Gillespie, 1986]. The younger, shallow rake deformation on both the Owens Valley and Rainbow Mountain fault zones is in agreement with the dominantly strike-slip character of recent earthquakes along this seismic belt [e.g., Doser, 1988; Beanland and Clark, 1995; dePolo et al., 1987; 1991]. These data suggest a recent change in stress regime (or equivalently, temporal fluctuations in relative stress magnitudes); however, as discussed below, the orientation of the minimum horizontal stress axes (the $\sigma_{3}$ axis) has apparently remained approximately fixed. The youngest set of deviatoric stress tensors determined geologically from fault slip measurements are shown to be remarkably consistent with the present-day strike-slip stress regime deduced from inversion of historic earthquake slips.

Because of the evidence for temporal changes in stress regime, we have divided the data into dominantly normal and 
Table 2. Location of Fault Striae Measurement Sites

\begin{tabular}{|c|c|c|c|c|}
\hline Site & Latitude, ${ }^{\circ} \mathrm{N}$ & Longitude, ${ }^{\circ} \mathrm{W}$ & Age $^{a}$ & Reference $^{b}$ \\
\hline 1 & 40.180 & 120.210 & $\mathrm{Q}+\mathrm{Ne} ?$ & 1 \\
\hline $1^{\mathrm{c}}$ & 40.156 & 120.283 & $\mathrm{Ne}$ & 1 \\
\hline 2 & 40.110 & 120.080 & $\mathbf{M z}$ & 1 \\
\hline $2^{c}$ & 40.095 & 120.067 & $\mathrm{Mz}$ & 1 \\
\hline 3 & 40.080 & 120.190 & $\mathrm{Mz}-\mathrm{Ne}$ & 1 \\
\hline $3^{c}$ & 40.098 & 120.219 & $\mathbf{M z}$ & 1 \\
\hline 4 & 40.250 & 119.880 & lM-P & 2 \\
\hline 5 & 40.288 & 119.854 & IM-P & 2 \\
\hline 6 & 40.355 & 119.836 & 1M-P & 2 \\
\hline 7 & 40.417 & 119.860 & lM-P & 2 \\
\hline 8 & 40.406 & 119.850 & $\mathbf{Q}$ & 2 \\
\hline 9 & 40.035 & 119.485 & mM-eP & $2,3,4,5$ \\
\hline 10 & 40.106 & 119.503 & $\mathrm{mM}-\mathrm{eP}$ & $2,3,4,5$ \\
\hline $10^{\mathrm{c}}$ & 40.170 & 119.510 & mM-eP & $2,3,4,5$ \\
\hline 11 & 40.027 & 119.301 & $\mathbf{Q}$ & 6 \\
\hline $11^{\mathrm{c}}$ & 40.050 & 119.290 & $\mathrm{Q}+\mathrm{lMz}$ & 6 \\
\hline $11^{\mathrm{c}}$ & 40.065 & 119.285 & $\mathrm{IMz}$ & 6 \\
\hline 12 & 39.680 & 119.380 & M-eP & 2 \\
\hline $12^{\mathrm{c}}$ & 39.650 & 119.426 & M-eP & 2 \\
\hline 13 & 39.800 & 119.377 & eM-mM & 2,3 \\
\hline 14 & 39.824 & 118.220 & Ol-eM & $2,7,8$ \\
\hline 15 & 39.402 & 119.850 & $\mathrm{mM}$ & $9,10,11$ \\
\hline 16 & 39.240 & 119.850 & $\mathbf{M z}$ & 6 \\
\hline 17 & 39.115 & 119.840 & Mz & 6,12 \\
\hline 18 & 39.060 & 119.845 & IMz & 6,12 \\
\hline 19 & 38.997 & 119.844 & $\mathrm{IMz}$ & $6,12,13$ \\
\hline 20 & 39.980 & 119.835 & $\mathrm{lMz}$ & $6,12,13$ \\
\hline 21 & 38.555 & 119.504 & $\mathrm{IMz}$ & 13 \\
\hline 22 & 38.680 & 119.550 & $\mathrm{e}+\mathrm{mMz}$ & 13 \\
\hline 23 & 38.735 & 119.355 & $\mathrm{eM}+\mathrm{mM}$ & 13,14 \\
\hline 24 & 38.780 & 119.400 & $1 \mathrm{Mz}$ & 14,15 \\
\hline 25 & 38.812 & 119.256 & $1 P$ & 13,14 \\
\hline 26 & 38.812 & 119.244 & IP & 13,14 \\
\hline 27 & 38.814 & 119.225 & $\mathrm{mM}-1 \mathbf{M}$ & 13,16 \\
\hline $27^{\mathrm{c}}$ & 38.814 & 119.216 & $\mathrm{mM}$-lM & 13,16 \\
\hline $27^{c}$ & 38.840 & 119.194 & $\mathrm{mM}$-lM & 13,16 \\
\hline 28 & 38.845 & 119.185 & $\mathbf{M}$ & 13,16 \\
\hline 29 & 38.875 & 119.170 & $1 \mathbf{M z}$ & 13 \\
\hline 30 & 38.895 & 118.850 & $1 \mathrm{Mz}$ & 13 \\
\hline 31 & 38.810 & 118.765 & $1 \mathrm{Mz}$ & 13 \\
\hline & to 38.830 & 118.770 & $\mathrm{lMz}+\mathrm{Q}$ & 13 \\
\hline 32 & 38.787 & 118.756 & $\mathrm{lMz}$ & 13 \\
\hline 33 & 38.710 & 118.768 & $1 \mathrm{Mz}$ & 13 \\
\hline 34 & 38.670 & 118.770 & $\mathrm{lMz}$ & 13 \\
\hline 35 & 38.350 & 118.035 & $\mathrm{lMz}$ & 13 \\
\hline 36 & 38.372 & 118.047 & $\mathrm{eMz}$ & 13 \\
\hline 37 & 37.900 & 118.340 & $\mathrm{Mz}$ & 6,17 \\
\hline 38 & 37.800 & 118.382 & $\mathrm{Mz}$ & 17 \\
\hline chalf & 37.540 & 118.315 & Pz-Mz & 17 \\
\hline 39 & 36.590 & 118.190 & $\mathbf{M z}$ & 18 \\
\hline 40 & 36.600 & 118.202 & $\mathbf{M z}$ & 18 \\
\hline \multicolumn{5}{|c|}{ Pleasant Valley Fault } \\
\hline $\mathrm{p} 1 \mathrm{v} 1$ & 40.381 & 117.580 & $\mathrm{IPz}$ & 6,16 \\
\hline p $1 \vee 2$ & 40.360 & 117.601 & $\mathbf{l P z}$ & 6,19 \\
\hline p1v3 & 40.320 & 117.620 & $\mathrm{eMz}$ & 6,19 \\
\hline $\mathrm{p} 1 \mathrm{v} 4$ & 40.300 & 117.630 & $\mathrm{eMz}$ & 6,19 \\
\hline p 1 v5 & 40.290 & 117.630 & $\mathrm{eMz}$ & 6,19 \\
\hline \multicolumn{5}{|c|}{ Dixie Valley Fault } \\
\hline $\mathrm{dv} 1$ & 39.555 & 118.212 & 10-eM & $6,7,8$ \\
\hline $\mathrm{dv} 2$ & 39.620 & 118.175 & 10-eM & $6,7,8$ \\
\hline dv3 & 39.790 & 118.105 & M-PI? & $6,7,8$ \\
\hline \multicolumn{5}{|c|}{ Fairview Peak Fault } \\
\hline fairv & 39.260 & 118.135 & $\mathrm{mM}-\mathrm{lM}$ & 6 \\
\hline fairv & 39.210 & 118.150 & $\mathrm{mM}-\mathrm{lM}$ & 6 \\
\hline
\end{tabular}

Table 2. (continued)

\begin{tabular}{|c|c|c|c|c|}
\hline Site & Latitude, ${ }^{\circ} \mathrm{N}$ & Longitude, ${ }^{\circ} \mathrm{W}$ & Age $^{a}$ & Reference $^{b}$ \\
\hline \multicolumn{5}{|c|}{ Rainbow Mountain Fault } \\
\hline $\mathrm{rm}$ & 39.440 & 118.526 & $\mathrm{mM}-\mathrm{IM}$ & 6 \\
\hline $\mathrm{rm}^{\mathrm{c}}$ & 39.420 & 118.535 & $\mathrm{mM}-\mathrm{lM}$ & 6 \\
\hline \multicolumn{5}{|c|}{ Owens Valley Fault } \\
\hline owens 1 & 37.145 & 118.290 & $\mathrm{Pl}$ & 18,20 \\
\hline owens 1 & 37.108 & 118.280 & Pl & 18,20 \\
\hline \multicolumn{5}{|c|}{ Olinghouse Fault } \\
\hline oling & 39.595 & 119.500 & $\mathrm{mP}-1 \mathbf{P}$ & 2 \\
\hline oling ${ }^{c}$ & 39.589 & 119.522 & mP-1P & 2 \\
\hline
\end{tabular}

a Ages of faulted formations are as follows: Q, undifferentiated Quaternary; Pl, Pleistocene; Ne, undifferentiated Neogene; eP, early Pliocene; $\mathrm{mP}$, middle Pliocene; IP, lower Pliocene; P, undifferentiated Pliocene; eM, early Miocene; mM, middle Miocene; $\mathrm{IM}$, lower Miocene; $M$, undifferentiated Miocene; 10 , late Oligocene; $\mathrm{Ol}$, undifferentiated Oligocene; eMz, Triassic; mMz, Jurassic; eMz, Cretaceous; Mz, undifferentiated Mesozoic; and $\mathrm{Pz}$, late Paleozoic.

b References used to date faulted formations are as follows: 1, Lydon et al. [1960]; 2, Bonham [1969]; 3, Everden and James [1964]; 4, Axelrod [1966]; 5, Silberman and McKee [1974]; 6, Stewart and Carlson [1976a, 1978]; 7, D. A. John and E. H. McKee (written communications, 1990); 8, Page [1965]; 9, Bonham and Rogers [1983]; 10, Vikre and McKee [1987]; 11, Whitebread [1976]; 12, Pease [1980]; 13, Stewart et al. [1982]; 14, Stewart and Dohrenwend [1984]; 15, Noble [1962]; 16, Proffett and Proffett [1976] and Proffett [1977]; 17, Strand [1967]; 18, Matthews and Burnett [1965]; 19, Stewart and Carlson [1976b]; and 20, Beanland and Clark [1995] and Lubetkin and Clark [1988].

c Multiple localities along the same fault zone. Data from all sites with same number or name are analyzed together.

strike-slip faulting stress regime subsets. This distinction allows for determination of stress tensors individually, to test whether the observed slip patterns are compatible with a single stress state (e.g. a stress state transitional between normal and strike-slip faulting) or if they require distinct stress states. Results of the stress inversion on both geologic and earthquake slip data are tabulated in Tables 3 and 4, summary stereoplots of individual inversion axes are shown in Figure 5, and stereoplots of the actual fault slip data are given in Figures 6 and 11. The computed $\sigma_{3}$ orientations are shown in map view on Figures 7 and 12 and are discussed below by stress regime and locality.

It is significant to note that we have strictly applied the quality criteria in Table 1 to our data. Only 10 of the 31 normal fault inversions given in Table 3 are considered wellconstrained, reliable results. Similarly, none of the results on small individual strike-slip data sets (Table 4) was judged to be well constrained; only the results on the combined data sets met the quality criteria in Table 1 . We have chosen to show inversion results for all data sets collected and to highlight the well-constrained results in Figures 5-6 and 11. 


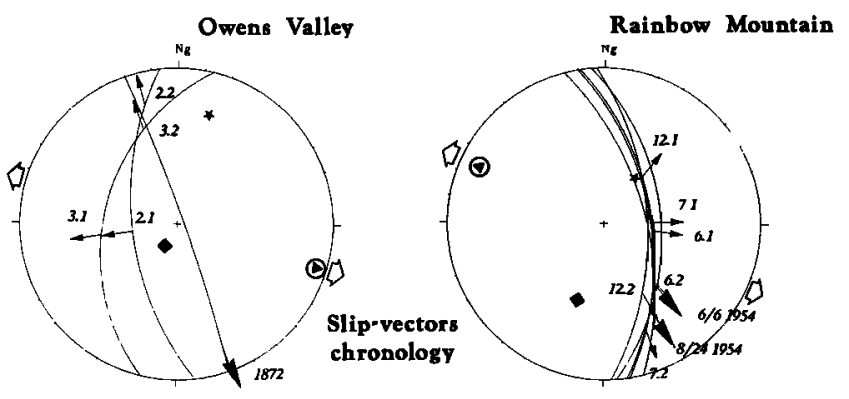

Figure 3. Lower hemisphere stereographic projection of faults with crosscutting families of striae measured along the Owens Valley and Rainbow Mountain fault zones. Arrows on fault planes point in the horizontal slip azimuth direction. The older slip vector on each fault plane is indicated by .1 suffix; the younger is given by .2 suffix. The slip vectors for historic earthquakes along each fault zone (data given in Table 5) are also plotted; 1872 is Owens Valley earthquake; June 6, 1954, and August 24, 1954, correspond to Rainbow Mountain earthquakes. Also given on each stereonet are the results of stress inversions on young fault slip data measured along the Owens Valley and the Rainbow Mountain faults (Table 4); $\sigma_{1}$ is given by a star; $\sigma_{2}$, a diamond; and $\sigma_{3}$ is shown by a circled triangle.

\section{Evidence for Basin-Range Normal Faulting Stress Regime}

Evidence for a "basin-range" extensional stage is found throughout the northern Basin and Range province. This deformational stage is characterized by a generally WNW trending extension direction [Zoback et al., 1981; Zoback, 1989]. We found this deformational stage recorded throughout the WLZ by slip on both minor and major faults which affect Plio-Quaternary fluvial, lacustrine, and colluvial deposits, and Quaternary volcanic flows, as well as Cenozoic and Mesozoic bedrock. The major faults bordering the ranges, including the normal fault zone forming the eastern boundary of the Sierra Nevada, also expose slickensides with striations, all indicating a roughly WNW trending extension.

Results of inversion of all fault slip data sets belonging to this extensional deformational stage are given in Table 3. Lower hemisphere stereoplots of all slip data and inversion results, including histograms of deviation angles (angle between the observed slip direction and that predicted from the maximum shear direction), are plotted in Figure 6; the wellconstrained results are indicated by the solid $\sigma_{3}$ arrows. Corresponding horizontal stress axes (with the wellconstrained results also highlighted) are plotted on the stereonet labeled NF/GEO in Figure 5, together with mean stress axes and their $95 \%$ confidence ellipses (determined independently using Fisher statistics, as modified by Watson [1960], on each subset of axes). Individual site $\sigma_{3}$ directions are shown on the geologic map in Figure 7. The data and results of the stress inversion are described below by geographic and tectonic setting, generally in the order they appear in Tables 2 and 3.

Sierra Nevada frontal fault zone. The NNW trending east facing Sierra Nevada frontal fault zone consists of steep, fresh-looking scarps which mark the trace of the fault. A series of large, fresh triangular facets in the footwall block provide slickensided bedrock fault exposures along portions of the fault zone. Examples of these striated bedrock fault exposures can be seen along the Genoa fault in Figure 8 (sites 17 to 20 , Figures 1 and 7) and along the Independence fault (from northwest of site owens 1 to south of site 40, Figures 1 and 7) which forms the west side of Owens Valley. These border fault traces also cut late Quaternary fluvial and colluvial deposits, producing surface fault scarps which are sometimes arranged in an en echelon pattern such as along the Jack Valley zone (south of Carson, near and between sites 17 and 18 in Figures 1 and 7). The profound relative vertical relief across the Sierra frontal fault zone and the large vertical offset of late Pleistocene glacial moraines with no detectable lateral offset [Clark et al., 1984; M. M. Clark, oral communication, 1988] attest to the dominantly dip slip character of this fault zone and imply a Pleistocene normal faulting stress regime.

Striations were measured on the major fault planes of the Sierran frontal fault zone and on secondary, associated fractures within the fault zone. The striations were typically located at the base of the major fault scarps, primarily within Late Cretaceous granitic bedrock. The slightly weathered slickensides showed well-preserved grooves and frictional striations. As indicated in Table 3 , all inversions yielded a normal faulting stress regime with $\sigma_{3}$ axes trending between WNW and about E-W. Only three of the datasets (sites 17, 21, and 39) yielded well-constrained inversion results (indicated by the crosses in Table 3); the stress axes for these were similar to the overall trends, varying between $\mathrm{WNW}\left(\mathrm{N} 57^{\circ} \mathrm{W}\right.$, site 17 ) and approximately E-W (N87 ${ }^{\circ} \mathrm{W}$ to $\mathrm{N} 98^{\circ} \mathrm{W}$, sites 21 and 39 respectively). Stress ratio values $R$ for the wellconstrained inversions range between 0.75 and 0.82 , indicating a stress state in which the two horizontal stresses are close in magnitude and much less than the vertical stress $\sigma_{1}$. These high $R$ values are a direct result of the fact that most deformation measured represents nearly pure dip-slip movement on fault planes with a rather wide range in strike.

Only the fault kinematics of the northernmost Sierran frontal fault (Honey Lake region, inversion from the combined sites 1,2 , and 3 ) are very discordant and indicate a NE trending $\sigma_{3}$ axis. Note on Figure 1, however, that the major Sierran bounding fault in this area strikes NW, thus the NE trending $\sigma_{3}$ axis may be due to extension in a normal faulting stress regime with $R=1$ (two horizontal stresses approximately equal in magnitude), in which case the $\sigma_{3}$ direction determined by the inversion would be strongly influenced by the overall orientation of the faults sampled. However, the NE trending $\sigma_{3}$ axis indicated by the inversion of the combined data from sites 1,2 , and 3 (Figure 7 and site $1 \& 2 \& 3$ in Table 3) may also represent a real rotation of $\sigma_{3}$ orientation in the northernmost Sierra Nevada/southern Cascade region. Volcanic vent alignments farther to the NW in the Lassen-Susanville region of northeastern California indicate (many $<1.0 \mathrm{~m} . \mathrm{y}$. old) indicate a NE to ENE $\sigma_{3}$ direction in that region [Luedke and Smith, 1981].

Range-bounding fault zones within the Basin and Range province. Numerous Basin and Range-type mountain blocks within the WLZ have recent scarps at their base, for example, the Dry Valley border fault shown in Figure 

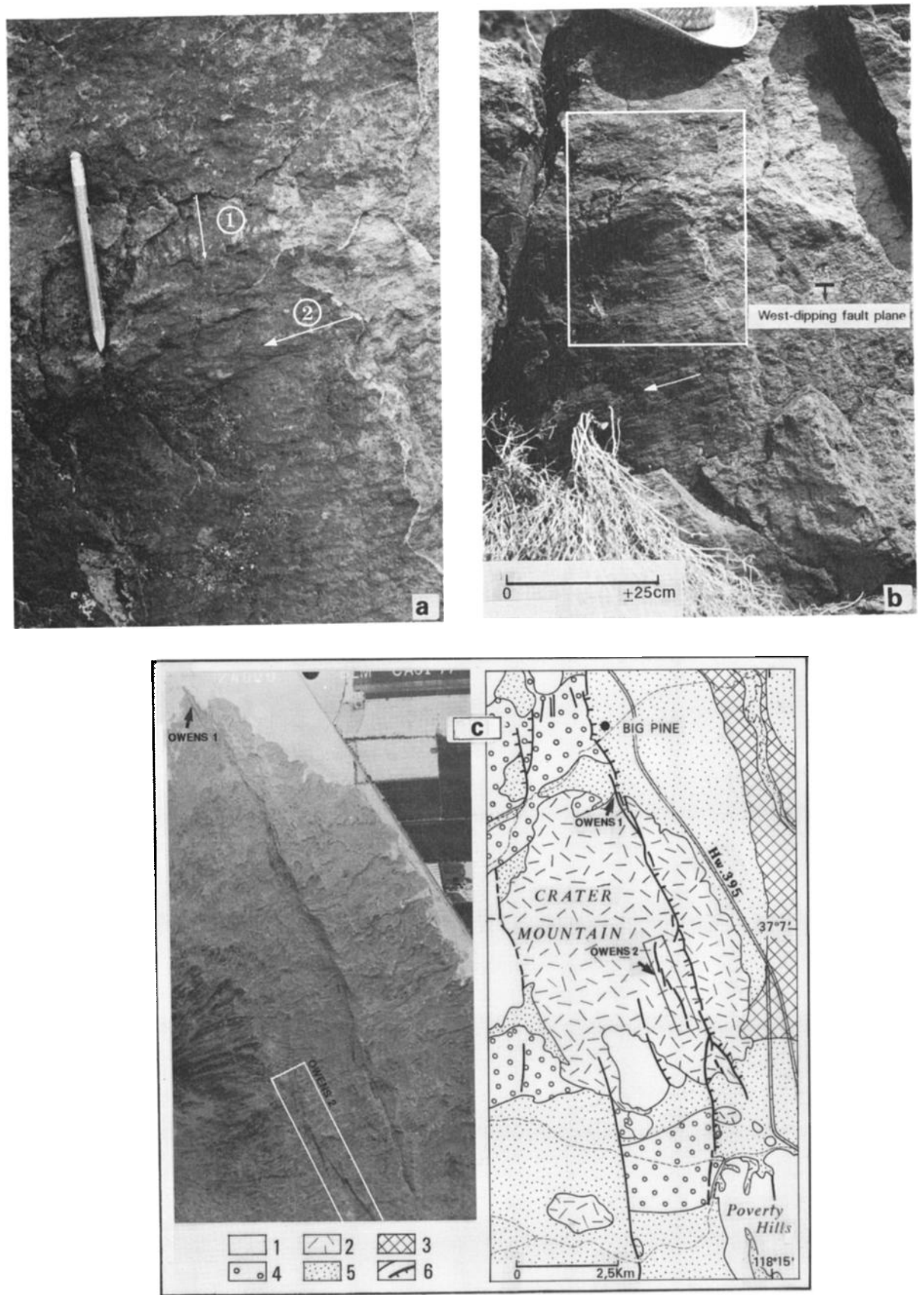

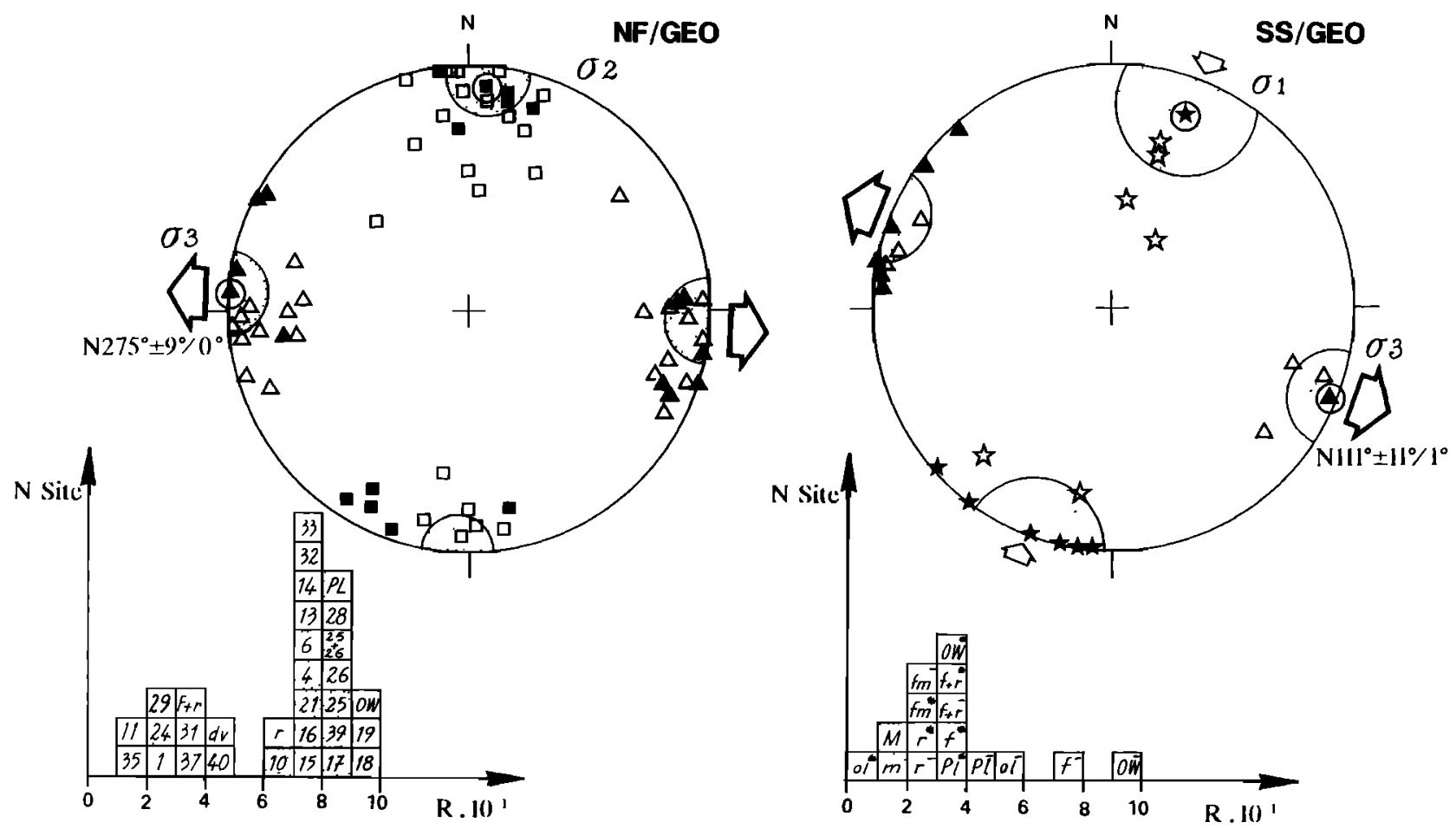

Figure 5. Late Neogene to present-day regional stress states in the Walker Lane zone. NF/GEO and SS/GEO are lower hemisphere summary stereoplots showing local "horizontal" stress axes determined by inversions for each individual site. NF/GEO shows results for the normal faulting inversions given in Table 3, while SS/GEO gives the more limited results for the strike-slip faulting inversions given in Table 4. Stars, squares, and triangles refer to the $\sigma_{1}, \sigma_{2}$, and $\sigma_{3}$ axis, respectively. For NF/GEO the results from well-constrained inversions (pluses in Table 3 ) are shown by solid symbols, while open symbols refer to results from poorly constrained inversions (minuses in Table 3). For SS/GEO the solid symbols refer to results of the fixed inversions (i.e., inversions in which the principal stresses are fixed to lie in horizontal and vertical planes; asterisks in Table 4), and open symbols indicate standard, poorly constrained inversions (minuses in Table 4). The encircled star, square, and triangle indicate the mean horizontal $\sigma_{1}, \sigma_{2}$, and $\sigma_{3}$ axes, respectively, determined by the Fisher statistics method (modified by Watson [1960]), to each of the local horizontal stress axes. Dotted areas correspond to $95 \%$ confidence cones for the mean directions. Histograms at bottom show distribution of computed mean stress ratio $R$ values for each individual inversion. Numbers inside the histograms refer to site numbers given in Table 2 and which correspond to labels outside of the individual stereoplots on Figures 6 and 11. The lettered sites are dv, Dixie Valley; pl, Pleasant Valley; f, Fairview Peak; r, Rainbow Mountain, $f+r$, combined Fairview Peak and Rainbow Mountain; ol, Olinghouse; ow, Owens 2; m, SS/g-minor; M, SS/g-major; fm, SS/fm. Dotted squares in histograms show $R$ values for the well-constrained inversions (pluses in Tables 3 and 4), while on the SS/GEO histogram the minus superscripts refer to $R$ values from poorly constrained standard inversions and the asterisk superscripts refer to $R$ values obtained from the fixed inversions.

Figure 4. (a) Close-up photograph of a fault plane within the Owens Valley fault zone cutting a late Pleistocene basalt flow (age $288 \pm 70 \mathrm{ka}$, [Turrin and Gillespie 1986]) and showing two crosscutting striae families (owens 2 site in Figures 1 and $4 \mathrm{c}$ ). The older striae (2.1) indicate normal slip and the younger (2.2) show right-lateral slip, these data are plotted on Figure 3. (b) A general view of the fault plane containing the crosscutting striae, large square shows area of the close-up photograph in Figure 4a. (c) Location of the fault striae measurement localities in Owens Valley on (left) a U.S. Geological Survey aerial photograph and (right) on a geological map after Beanland and Clark [1995]. Rectangle on left inset indicates the owens 2 fault zone which contains the fault plane depicted in Figures 4a and 4b. Legend for geological map on right is: (1) preCenozoic bedrock, (2) Pleistocene basalt ( $<300,000$ years in age), (3) Pleistocene lake sediments, (4) Pleistocene fanglomerates, (5) late Pleistocene to early Holocene fan deposits, and (6) 1872 fault rupture trace. 
9 (sites 4 and 5 in Figures 1 and 7). In most cases this faulting occurs mainly at or near the alluvial/bedrock range front boundary, and these faults bound asymmetric, graben-ingraben structural basins [e.g., Slemmons, 1957; Thompson and Burke, 1973; Anderson et al., 1983; Wallace, 1984a]. Fault slip data were collected along these major normal fault planes and from secondary fractures within the fault zone. The studied striations are mechanical striations in volcanic, granitic, and sedimentary rocks.

Results of the inversions of all these range-bounding fault slip data are given in Table 3 , and the actual fault data are shown in Figure 6. The inversion results indicate a normal faulting stress regime with $\sigma_{3}$ axes trending between WNW to about $\mathrm{E}-\mathrm{W}$ (between $\mathrm{N} 61^{\circ} \mathrm{W}$ and $\mathrm{N} 95^{\circ} \mathrm{W}$, with one site, 32, somewhat discordant with a $\sigma_{3}$ axis trending $\mathrm{N} 109^{\circ} \mathrm{W}$ ). The $\sigma_{3}$ axes for the well-constrained inversions covered the entire range and included the somewhat discordant site 32. The $R$ values for four of the five well-constrained, high-quality inversions were very consistent, varying between 0.68 and 0.77 , similar to those determined from the well-constrained inversions along the Sierran frontal fault zone. One wellconstrained inversion (site 24), however, yielded a much smaller $R$ value, 0.24 .

Minor faulting in Plio-Quaternary deposits. Faults with minor displacements (1-2 m) cutting PlioQuaternary fluvio-lacustrine and volcano-sedimentary deposits that infill the present-day basin-range grabens were observed at several sites within the WLZ (sites $1,11,25,26,28$, and 31 in Figure 1). Unfortunately, striations are rarely preserved in such poorly consolidated deposits. The best example of these faults, exposed by a road cut in Smith Valley, is shown in Figure 10 (sites 25 and 26 in Figure 1). Here the faulting cuts Pliocene sedimentary deposits of the Wilson Canyon formation, a poorly consolidated silt, sand, and gravel unit

Table 3. Results of Stress Tensor Inversion for Slip Data Representing Basin-Range Normal Faulting Stress Regime

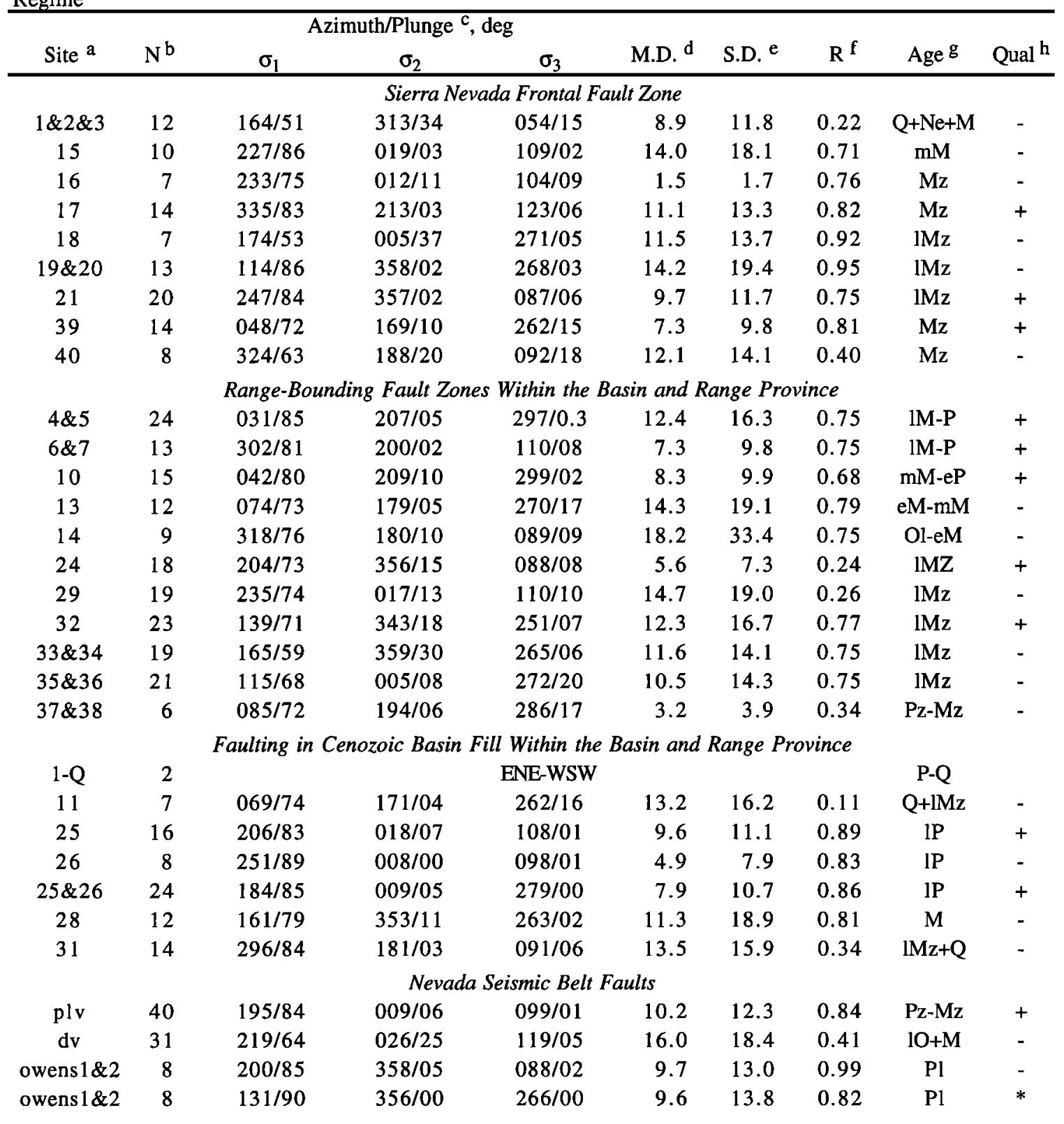


Table 3. (continued)

\begin{tabular}{|c|c|c|c|c|c|c|c|c|c|}
\hline \multirow[b]{2}{*}{ Site $^{a}$} & \multirow[b]{2}{*}{$\mathrm{N}^{\mathrm{b}}$} & \multicolumn{3}{|c|}{ Azimuth/Plunge ${ }^{c}$, deg } & \multirow[b]{2}{*}{ M.D. ${ }^{d}$} & \multirow[b]{2}{*}{ S.D. e } & \multirow[b]{2}{*}{$\ddot{R}^{f}$} & \multirow[b]{2}{*}{ Age $\mathrm{g}$} & \multirow[b]{2}{*}{ Qual $^{h}$} \\
\hline & & $\sigma_{1}$ & $\sigma_{2}$ & $\sigma_{3}$ & & & & & \\
\hline fairv & 4 & vertical & & ENE-WSW & & & & $\mathrm{mM}+\mathrm{IM}$ & \\
\hline $\mathrm{rm}$ & 11 & $216 / 69$ & $342 / 13$ & $076 / 16$ & 7.4 & 12.3 & 0.55 & $\mathrm{mM}+\mathrm{lM}$ & - \\
\hline $\mathrm{rm}$ & 11 & $153 / 90$ & $355 / 00$ & $265 / 00$ & 10.2 & 14.6 & 0.66 & $\mathrm{mM}+\mathrm{lM}$ & $*$ \\
\hline \multirow[t]{2}{*}{ fair\&rm } & 15 & $154 / 90$ & $344 / 00$ & $254 / 00$ & 15.0 & 17.2 & 0.31 & $\mathrm{mM}+\mathrm{lM}$ & $*$ \\
\hline & & & & All Data & & & & & \\
\hline \multirow[t]{2}{*}{ NF/GEO' } & & & $5 \pm 8 / 04$ & $275 \pm 9 / 0.2$ & & & 0.63 & & \\
\hline & & & & & & & $0.74 Q$ & & + \\
\hline
\end{tabular}

${ }^{a}$ Ampersands indicate an inversion solution computed from data from two or more different sites. For example, $1 \& 2 \& 3$ corresponds to an inversion computed from data set 1,2 , and 3 . Site $1-Q$ is the Pliocene-Qualernary age shriae only at site 1 . Sites plv and $d v$ represent inversions of all normal striae collected at all the sites along the Pleasant Valley and Dixie Valley fault zones (p1v1 to p1v5 and dv1 to dv3, respectively). Other named sites include: owens 1\&2; Owens Valley Fault; fairv, Fairview Peak fault; rm, Rainbow Mountain fault.

${ }^{\mathrm{b}} \mathrm{N}$ is number of striated fault planes used to compute the solutions.

c Deviatoric principal stress axes $\sigma_{1}>\sigma_{2}>\sigma_{3}$, specified by azimuths measured clockwise from north and plunges measured from horizontal.

d M.D. is the mean deviation angle (defined in Table 1).

e S.D. is the standard deviation of deviation angle (defined in Table 1).

${ }^{f} R$ equals $\left(\sigma_{2}-\sigma_{1}\right) /\left(\sigma_{3}-\sigma_{1}\right)$, the "stress ratio" of the deviatioric stress tensor.

$\mathrm{g}$ Ages are same as in Table 2.

h Qual refers to the quality of the stress inversion; crosses indicate a well-constrained inversion as defined in Table 1, minuses indicate inversion results which did not meet the quality criteria in Table 1 , and asterisks indicate a fixed inversion (stress axes constrained to lie in horizontal and vertical planes).

i NF/GEO is the mean an average regional deviatoric axes determined using Fisher statistics independently on the two subhorizontal stress axes from each of the individual inversions. The $R$ value is the arithmetic mean of all sites, second $R$ value (followed by $\mathrm{Q}$ ) is the mean for only well constrained sites (crosses in Qual column).

[Stewart and Dohrenwend, 1984]. The majority of the fault planes strike NNE to NNW and are imprinted by very thin normal (dip slip) frictional striations on silt-clayish slickensides which agree roughly with a west to WNW trending extension (see stereoplots in Figure 10). As given in Table 3, inversion of these striations from two sites yield consistent results, indicating a normal faulting stress regime with $\sigma_{3}$ axes which trend $\mathrm{N} 82^{\circ} \mathrm{W}$ (site 26) and $\mathrm{N} 72^{\circ} \mathrm{W}$ (site 25) and $R$ values which vary between 0.83 and 0.89 (although only results for site 26 with the small mean deviation angle and standard deviation are considered well constrained). Results of inversion of the combined data from sites 25 and 26 (25\&26 in Figure 10 and Table 3 ) yield a well-constrained solution which confirms the local individual site inversions and indicates a normal faulting stress regime with a $\mathrm{N} 81^{\circ} \mathrm{W}$ trending $\sigma_{3}$ axis and an $R$ value of 0.86 .

Inversions of fault slip data from the other sites in PlioQuaternary deposits which showed normal faulting slip vectors generally agree with an approximately E-W trending $\sigma_{3}$ axis (sites 11, 28, and 31 in Figure 6 and Table 3) and yielded $R$ values ranging between 0.11 and 0.81 . However, all these inversions are poorly constrained because of the restricted distribution of fault trends (all faults were dipping in approximately the same direction). Only two striations were measured at site $1-Q$ so these data were not inverted.

Range-bounding fault zones within the Nevada Seismic Belt. Many of the range-bounding fault zones within the WLZ and adjacent parts of the western Basin and Range province have been reactivated in historic earthquakes, defining the Nevada Seismic Belt [see Slemmons, 1957;
Wallace, 1984b; Bell and Katzer, 1990; dePolo et al., 1991]. Many of these Nevada Seismic Belt fault zones were sampled in this study (see Figure 1 for localities): Pleasant Valley (sites plv1 to plv5), Dixie Valley (sites dv1 to dv3), Fairview Peak (site fairv), Rainbow Mountain (site rm), and Owens Valley (site owens 1\&2). These fault zones typically have recent scarps at their base which occur at, or near, the alluvial and colluvial/bedrock range front boundary. The Dixie Valley and the Rainbow Mountain fault zones also have associated minor surface ruptures which propagated outward into basins. Only the Owens Valley fault zone is located completely within a basin; this basin is bounded on the west by a part of the Sierra Nevada frontal fault zone, the Independence fault zone. The slip data come from mechanical striations collected along the major normal fault planes and from secondary fractures within the fault zone. The studied striae affect late Miocene to early Pleistocene volcanism and Paleozoic to Cenozoic granitic and sedimentary rocks.

The actual fault data are shown in stereoplots in Figure 6. The inversion results are given in Table 3 and indicate a normal faulting stress regime with an approximately WNW to west trending least principal stress. Only the Pleasant Valley fault zone data set (plv) yielded well-constrained results from the standard inversion, a normal faulting stress regime with a $\mathrm{N} 81^{\circ} \mathrm{W}$ trending $\sigma_{3}$ axes, and an $R$ value of 0.84 . This $R$ value is very consistent with the other $R$ values determined from the well-constrained inversions within the WLZ, including along both the Sierran frontal and range-bounding fault zones. Note that for several of the data sets (owens $1 \& 2, \mathrm{rm}$, and fairvw\&rm), both fixed and standard inversions were 

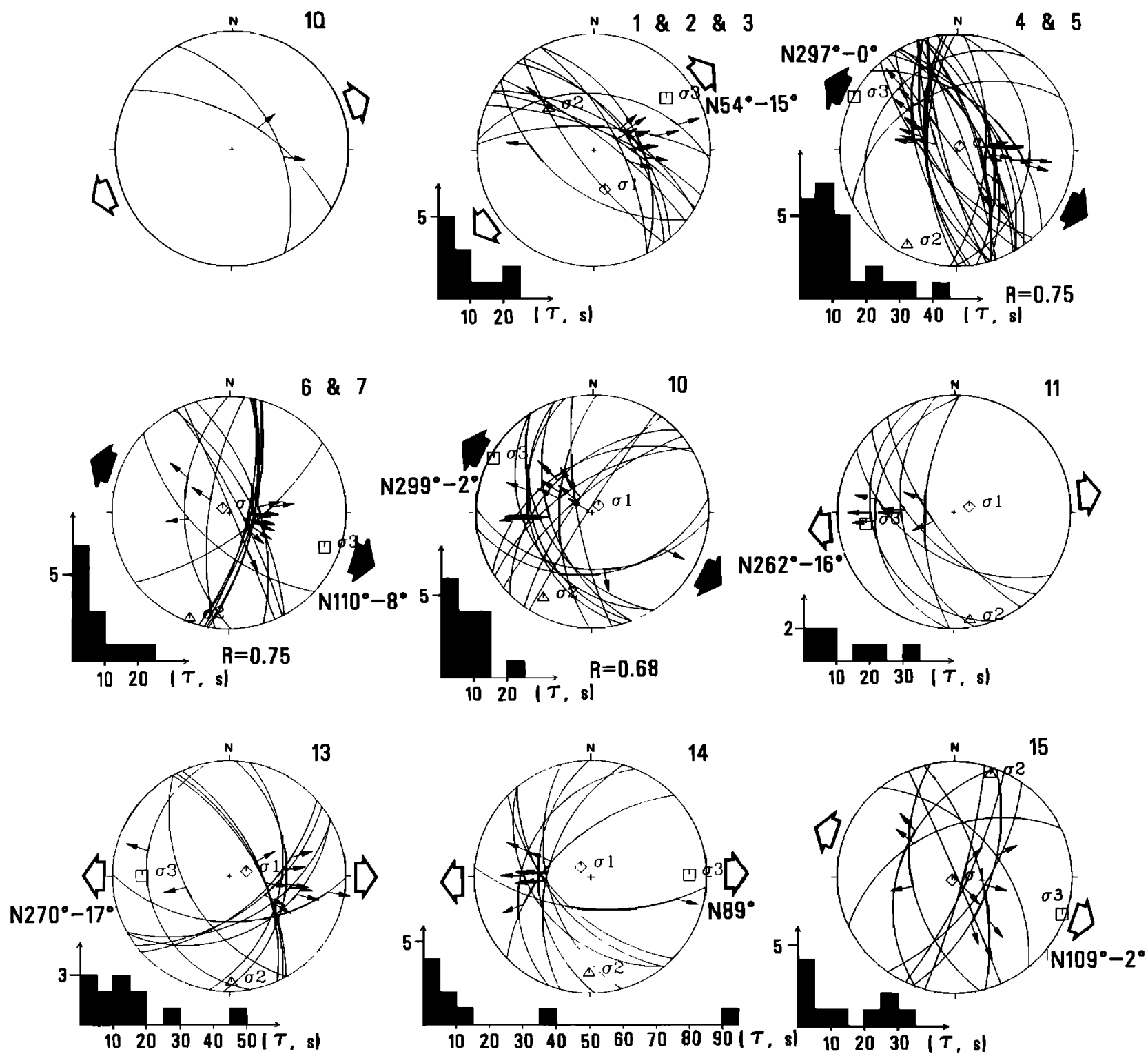

Figure 6. Lower hemisphere stereoplots of normal faulting slip data from the Walker Lane region, together with inversion results presented in Table 3. Labels outside and to top right of stereoplots refer to site names and numbers shown in Figure 1 and described in Table 2. Individual fault planes and measured slip vectors at each site are plotted, arrows on fault planes point in the directions of the horizontal azimuth of the slip vector. Solid lines on the individual fault planes give the deviation angle between measured $s$ and predicted $\tau$ slip vectors on each fault plane. Stress axes obtained from the inversions are given by diamonds $\left(\sigma_{1}\right)$, triangles $\left(\sigma_{2}\right)$, and squares $\left(\sigma_{3}\right)$. Large arrows outside stereoplots give azimuth of least horizontal stress $\left(\sigma_{3}\right)$. Results from well-constrained inversions (pluses in Table 3) are shown by solid stress axes symbols and solid outer arrows. Results of either fixed or poorly constrained standard inversions are represented by open symbols and arrows. Histograms below each stereplot show distribution of deviation angles. $R$ values for the wellconstrained inversions are given outside and to the bottom right of the stereoplots.

performed (with the results of the fixed inversion indicated by the asterisk in Table 3); in all three cases the distribution of the sampled faults did not satisfy the four independent fault set criteria. It is interesting to note that the fixed solutions all have $\sigma_{3}$ azimuths within $10^{\circ}$ of the standard (but not wellconstrained) inversion results. In contrast, a large and welldistributed data set was collected along the Dixie Valley fault zone (dv); however, the inversion results are rather inhomogeneous with a large mean deviation angle suggesting possible superimposed slip events that were, unfortunately, not recognized by field observations.

Summary of geologic fault slip data on Basin and Range extensional deformation stage. Striae corresponding to the "basin and range" extensional 

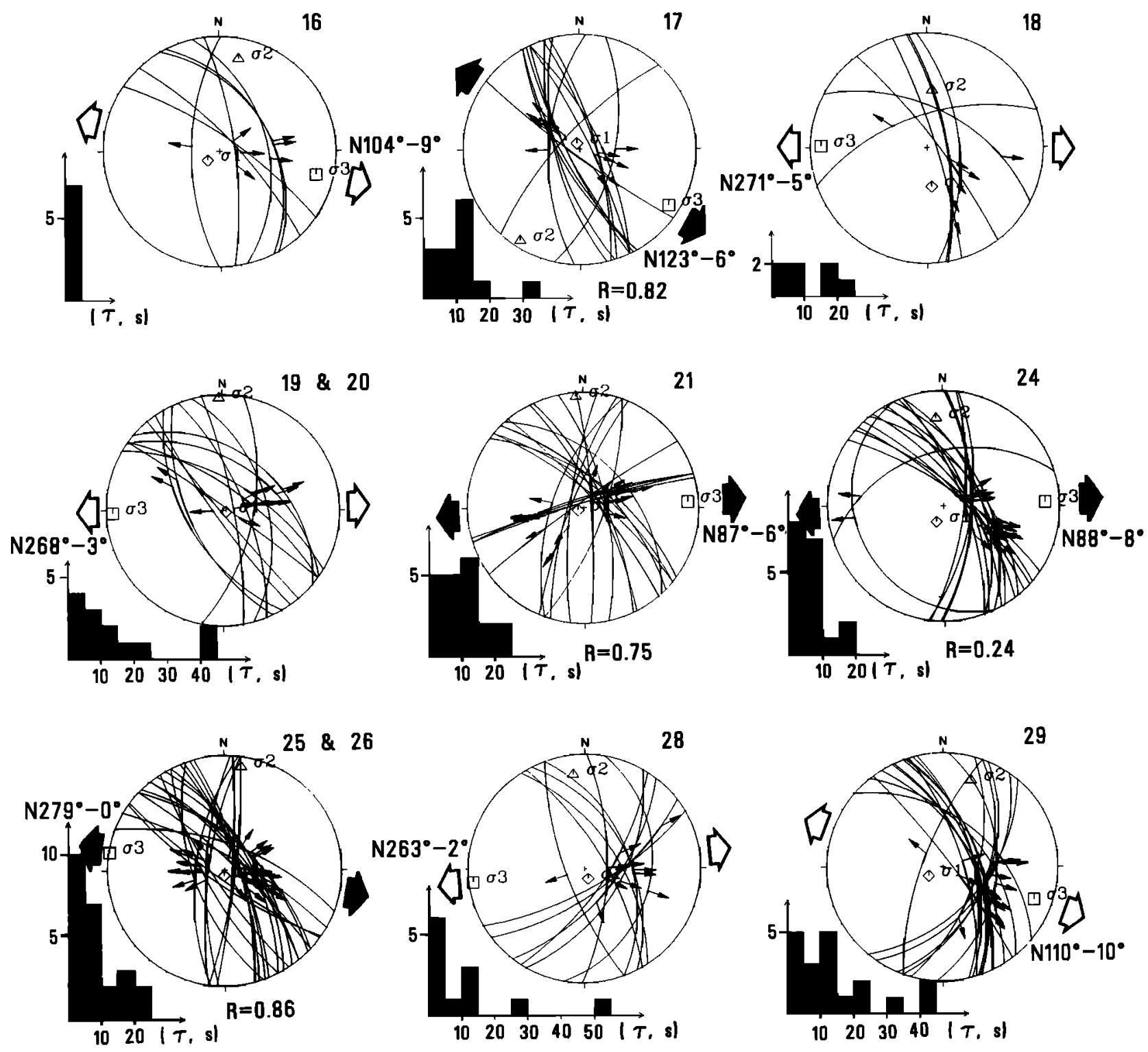

Figure 6. (continued)

deformation stage found in the four regions described above consistently indicate a normal faulting stress regime with an $\sigma_{3}$ direction between WNW and E-W, as shown in Figures 5, 6, and 7. A Fisher statistics analysis done on the two sets of individual site subhorizontal stress axes for the entire geologic fault slip data set yields a mean $\sigma_{3}$ (or $\sigma_{h \text { min }}$ ) axis trending $\mathrm{N} 95^{\circ} \pm 9^{\circ} \mathrm{W}$ with a plunge of $0.2^{\circ}$ and a mean $\sigma_{2}$ (or $\sigma_{H \text { max }}$ ) axis trending $\mathrm{N}^{\circ} \pm 8^{\circ} \mathrm{E}$ with a plunge of $4^{\circ}$ (see solution NF/GEO in Figure 5 and Table 3). The 8-10 $0^{\circ}$ uncertainties quoted in mean stress azimuths correspond to the radius of the 95\% cone of confidence in Fisher statistics. Stress ratios $(R$ values) obtained for this normal faulting deformation stage are generally $>0.50$ (Table 3 ). The arithmetic mean value for all inversions listed in Table 3 is $R=0.63$, which is similar to the mean $R$ value, $R=0.74$, determined for only the 11 wellconstrained inversions given in Table 3. Both $R$ values are clearly distinct from a "transitional to strike-slip" stress state (characterized by $R \approx 0$; i.e., $\sigma_{2} \approx \sigma_{1}$ ) and from a "radial extension" stress state (characterized by $R \approx 1$; i.e., $\sigma_{2} \approx \sigma_{3}$ ). However, a few sites, including two with high quality inversions, yielded very large $R$ values $(R>0.85)$, implying a local stress state close to the uniform radial extension. Not surprisingly, as shown in Figure 5, the sites with these large $R$ values (notably from inversions 18, $19 \& 20,25$, and $25 \&$ 26) are characterized by slip data with very steep rakes on normal faults with a wide range in strike.

\section{Evidence for Recent Strike-Slip Faulting Stress Regime}

Both historic earthquake slip and the youngest geologic striae data measured provide evidence for a contemporary, dominantly strike-slip stress regime in the WLZ. Along the Nevada Seismic Belt in easternmost California and westernmost Nevada, numerous historic and Holocene earthquake scarps along the major faults are associated with en 

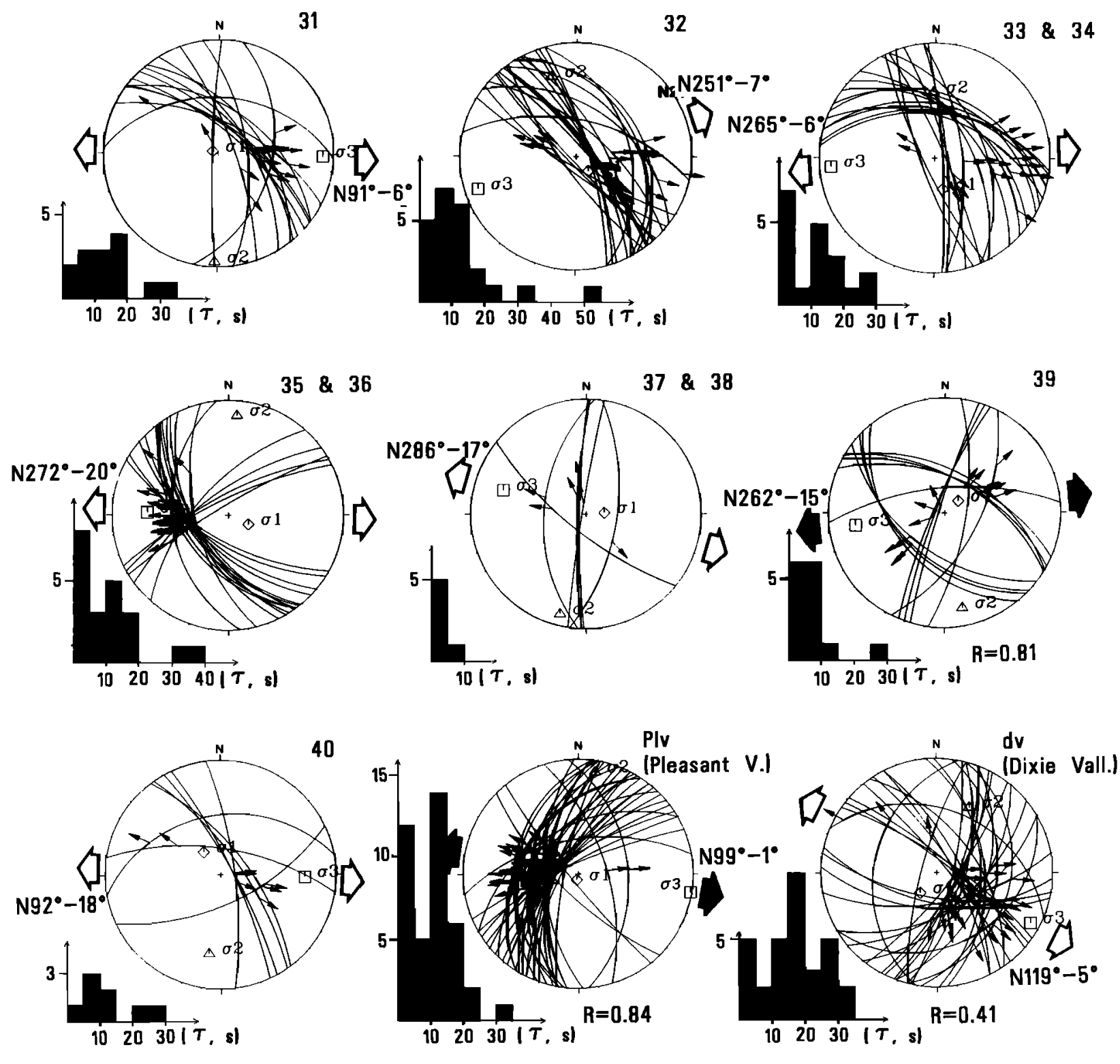

Figure 6. (continued)

echelon ruptures and discontinuous ruptures, strongly suggestive of a strike-slip component in the last event [e.g., dePolo et al., 1989, 1991]. Major (at the fault scarp offset scale) and minor (at the slickenside scale) deformation along the Nevada Seismic Belt shows evidence of a recent change in stress state. This change is clearly demonstrated by families of crosscutting striae which show differences in rake angle of 65 $\pm 15^{\circ}$ (Figure 3 ) measured along both the Owens Valley and the Rainbow Mountain fault zones. Along both fault zones the older striae set (marked by a .1 at the end of the fault plane number in Figure 3 ) records a normal faulting slip episode overprinted by younger (marked by a .2 at the end of the fault plane number in Figure 3), right-lateral strike-slip faulting. As shown in Figure 4, this youngest slip is recorded geologically in parallel, rough grooves and thin frictional strike-slip striations along small faults in basalts dated at $288 \pm 70 \mathrm{ka}$ [Turrin and Gillespie, 1986] which are parallel to the main
Owens Valley fault zone and located $600-700 \mathrm{~m}$ to the west (Figure 4c). (See appendix for more a detailed description of this site locality.)

The young strike-slip striae along the Owens Valley fault zone indicate a slip direction which is in excellent agreement with the historic (1872) seismic slip on the main fault zone, as determined by detailed surface fault offset studies [Beanland and Clark, 1987, 1995] (Figure 3). Similarly, the youngest striae along the Rainbow Mountain fault zone are also in good agreement with slip determined from focal mechanism studies of the 1954 earthquakes [Doser, 1986, 1988]. Thus slip vectors recorded both by the youngest near-surface striations and historic earthquakes appeared to have occurred in response to the same or very similar stress state. The clear chronological relationship between an older normal faulting event and a younger strike-slip faulting event recorded by crosscutting striae in young basalts adjacent to the Owens 

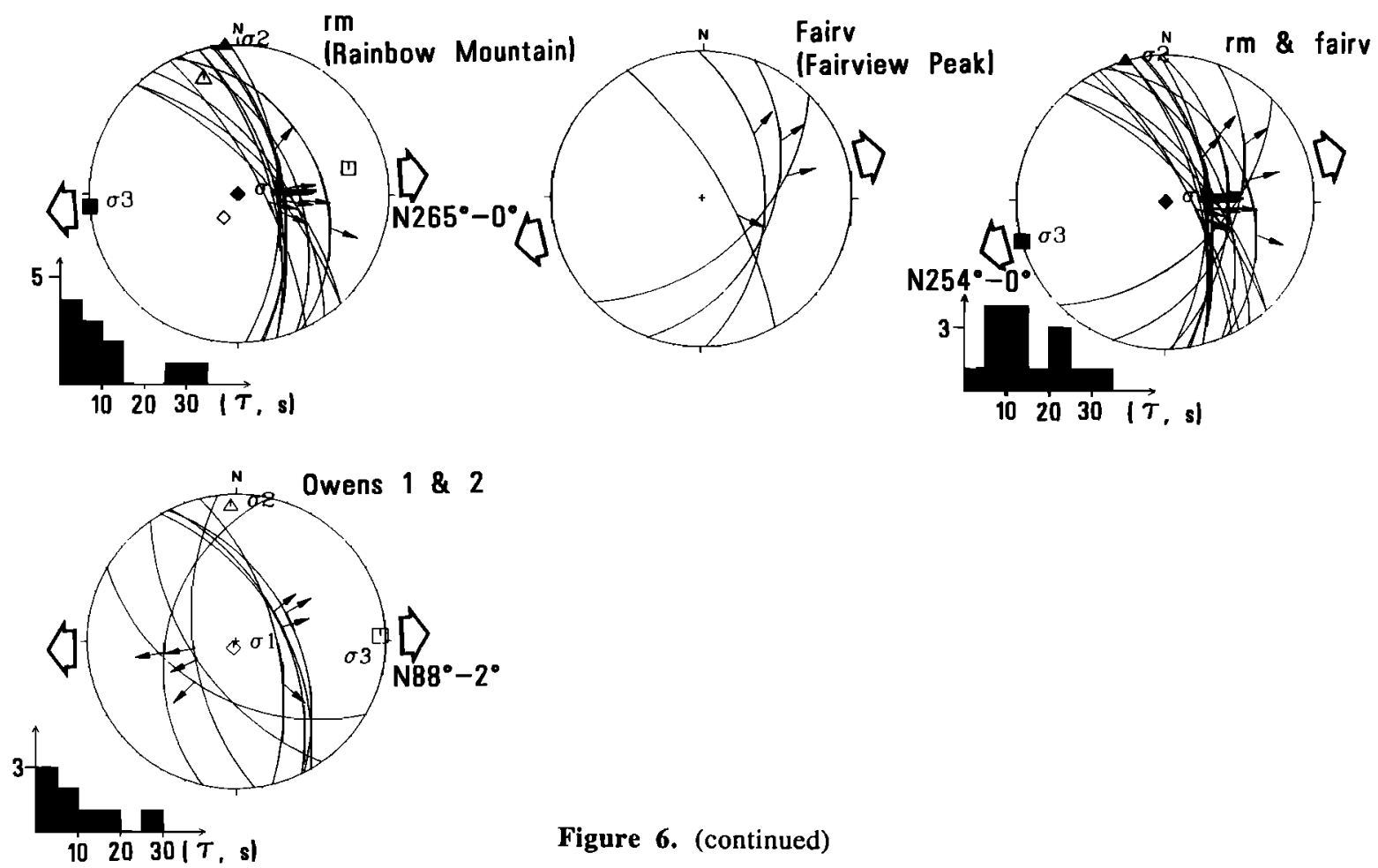

Figure 6. (continued)

Valley fault zone is consistent with the contrast between large-scale late Pleistocene pure dip-slip displacement and dominantly strike-slip 1872 earthquake offset on subparallel major faults in the Owens Valley region time reported by Zoback and Beanland [1986] and Zoback [1989].

Geologic evidence for recent strike-slip faulting stress regime. Striae indicating very young strike-slip deformation were measured at five sites, all along fault zones with historic offsets; the Olinghouse, Fairview Peak, Rainbow Mountain, Pleasant Valley, and Owens Valley fault zones (Figure 1). The slip data were measured both on major fault planes and within adjacent secondary faulting in late Neogene and Quaternary volcanic rocks as well as in Paleozoic and Cenozoic bedrock; the measured slip data are shown on lower hemisphere stereoplots in Figure 11. The results of the stress inversions are tabulated in Table 4 . Unfortunately, none of the inversions for the individual young strike-slip sites can be considered well constrained because all of the data sets contained only a small number of striae on fault planes with limited distributions, generally only defining three independent sets of fault planes. For this reason, all of the data were also inverted using a fixed inversion in which the stress axes are restricted to lie in horizontal and vertical planes; the results of the fixed inversions are indicated by asterisks in Table 4 . Both the standard and the fixed inversions indicate a NW to west trending $\sigma_{h \text { min }}$ direction ( $\sigma_{3}$ axes varying between $\mathrm{N} 41^{\circ} \mathrm{W}$ and $\mathrm{N} 82^{\circ} \mathrm{W}$ ). Interestingly, the orientation of the horizontal stress axes were generally very similar between the standard and the fixed inversions (typically within $5-10^{\circ}$ ). Individual site $\sigma_{3}$ and $\sigma_{1}$ directions are shown in Figure 12.

The subhorizontal stress axes $\left(\sigma_{3}\right.$ and $\left.\sigma_{1}\right)$ determined by both the standard and fixed inversions of the five individual (plv, fairv, rm, oling and owens 2 in Table 4) and one combined (fairv\&rm in Table 4) data sets are shown on the SS/GEO lower hemisphere stereoplot in Figure 5. A mean regional stress state was determined from the horizontal stress axes determined by both standard and fixed inversions using the Fisher statistic method (modified by [Watson, 1960]). The Fisherian mean $\sigma_{3}$ axis for the results from these 12 inversions (SS/GEO in Table 4 and Figure 5) trends N69 $11^{\circ} \mathrm{W}$ (with a plunge of $1^{\circ}$ to the ESE), while the Fisherian mean $\sigma_{1}$ axis trends $\mathrm{N} 21 \pm 17^{\circ} \mathrm{E}$ (with a plunge of $8^{\circ}$ to the NNE).

Although the inferred stress directions did not vary more than $\sim 10-15^{\circ}$ between the fixed and the standard inversions, the $R$ values were, in some cases, significantly different (Table 4). Only the $R$ values from the standard (not fixed) inversions are considered reliable since the criterion of 4 independent fault sets (the minimum to define the complete stress tensor and $R$ value was not met by the smaller data sets). The $R$ values determined by the standard inversions are consistently between 0.0 and 0.33 , with a mean value of $0.25\left(R\left(^{*}\right)=0.25\right.$ in Table 4, also see histogram on Figure 5). Recall that an $R$ value close to 0.0 indicates a stress state transitional between strike-slip and normal faulting.

In an attempt to constrain the parameters of this strike-slip stress state at a regional scale, we also did a combined inversion including slip data from all five sites. The data were separated into two subsets, one containing striae measurements on the major fault planes and a second set including striae on minor fault planes adjacent to the main exposed fault plane. The inversion of the major fault population (SS/g-major in Figure 11 and Table 4) yields a well-constrained and stable result (mean deviation angle of $5.7^{\circ} \pm 8.3^{\circ}$ ) with a horizontal $N 65^{\circ} \mathrm{W}$ trending $\sigma_{3}$ axis and $R=$ 0.11 , indicating a regional strike-slip stress state transitional 


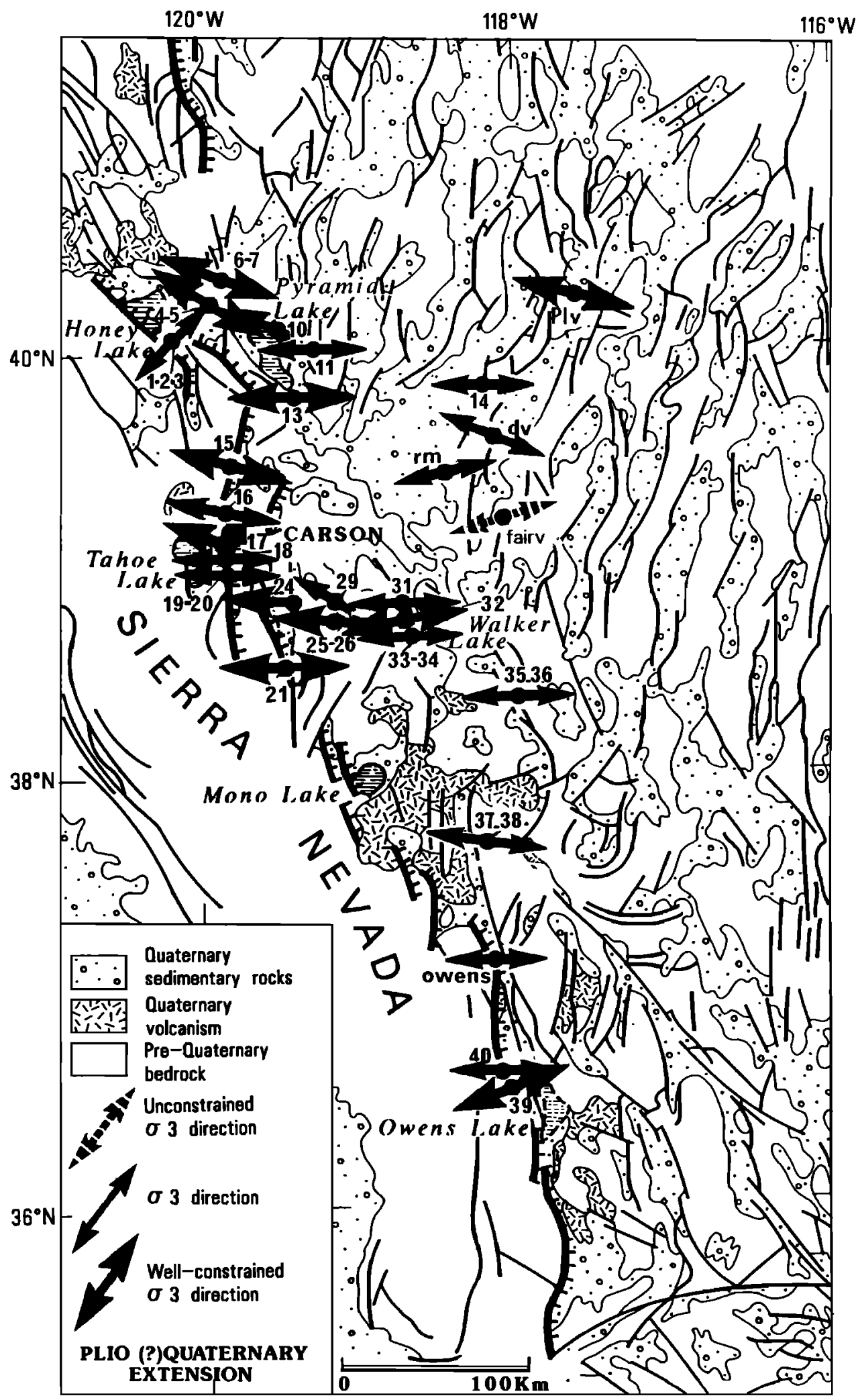

Figure 7. Azimuths of $\sigma_{3}$ (least horizontal stress) axes for the normal faulting stress regime deduced from fault slip inversions given in Table 3 and shown in Figure 6. Larger solid arrows plot $\sigma_{3}$ axes determined from well-constrained inversions (pluses in Table 3); smaller solid arrows are deduced from the poorly constrained inversions (minuses in Table 3); and the dashed arrow is a graphically determined $\sigma_{3}$ direction compatible with the few normal slip data measured at Fairview Peak. 


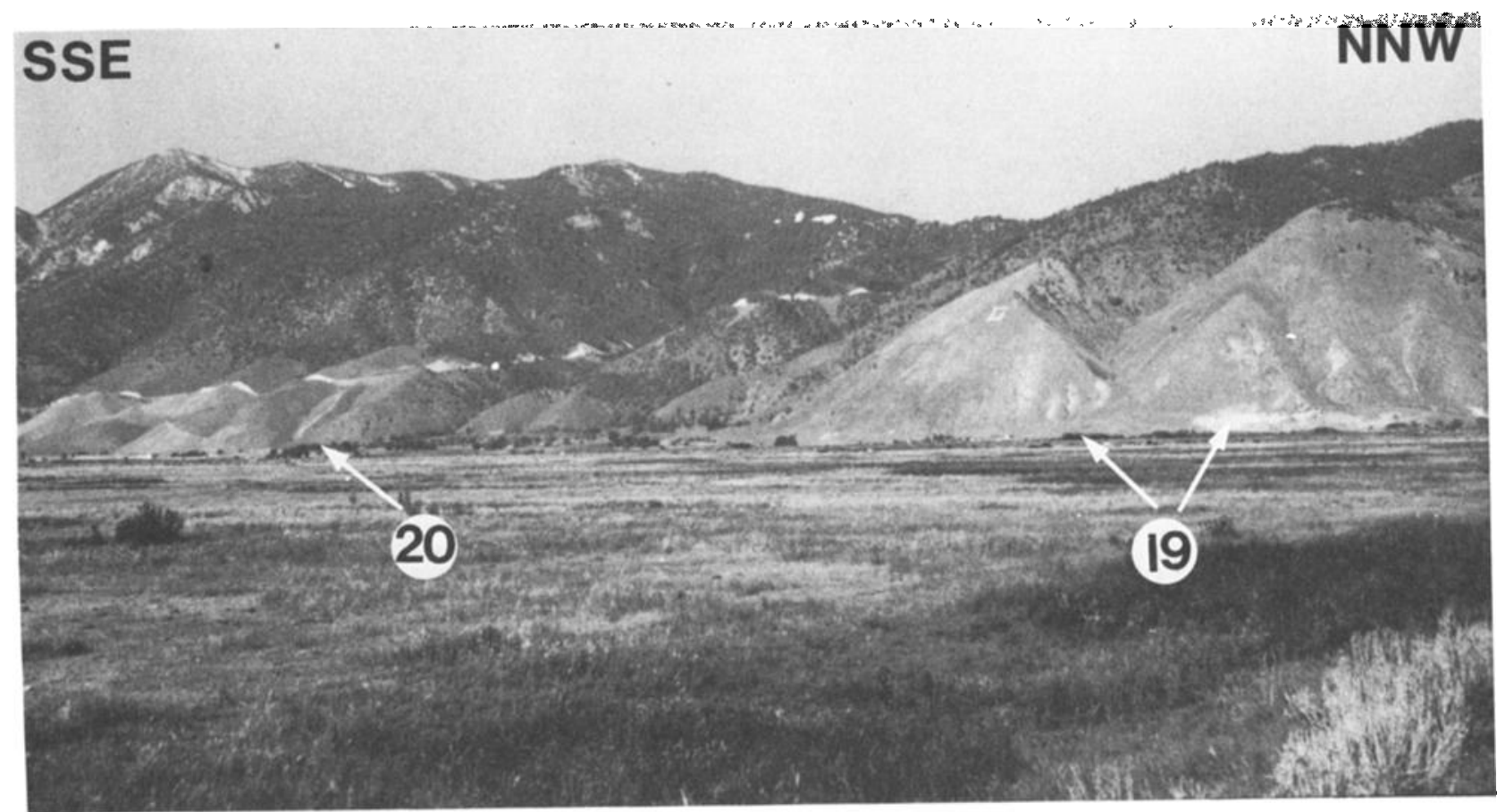

Figure 8. View looking southwest of the Genoa fault scarp. Arrows point to the two fault slip measurement sites along this fault zone (sites 19 and 20; see Table 2 for precise locations).

to normal faulting. Results of the combined inversion using data from significant minor faults at all five sites (SS/g-minor in Figure 11 and Table 4 ) yielded very similar results with a $\mathrm{N} 70^{\circ} \mathrm{W} \sigma_{3}$ axis and with $R=0.19$.

As can be discerned from Table 4 , there is remarkable similarity between the three geologically determined regional strike-slip stress states, inversions SS/g-major and SS/gminor as well as the Fisherian mean based on individual site inversions, SS/GEO. All three of these separately inferred stress states are characterized by $\sigma_{3}$ axes trending $\mathrm{N} 65-70^{\circ} \mathrm{W}$ and $R$ values ranging between 0.11 and 0.25 .
Present-day strike-slip stress regime inferred from historic seismic offsets. A NE to NNE trending zone of active seismicity crossing the WLZ region (the Nevada seismic belt in Figure 1) has been the locus of a series of large $(M>6)$ earthquakes accompanied by surface-faulting events during the last century [e.g., dePolo et al., 1989, 1991; Wallace, 1979, 1984b, 1987; Bell, 1981, 1984a, 1984b; Bell et al., 1984]. Twelve NNW to NNE trending faults were reactivated along this zone during earthquakes occurring between 1872 and 1986 (Table 5). These faults represent a variety of structural styles from right-lateral strike-slip, and

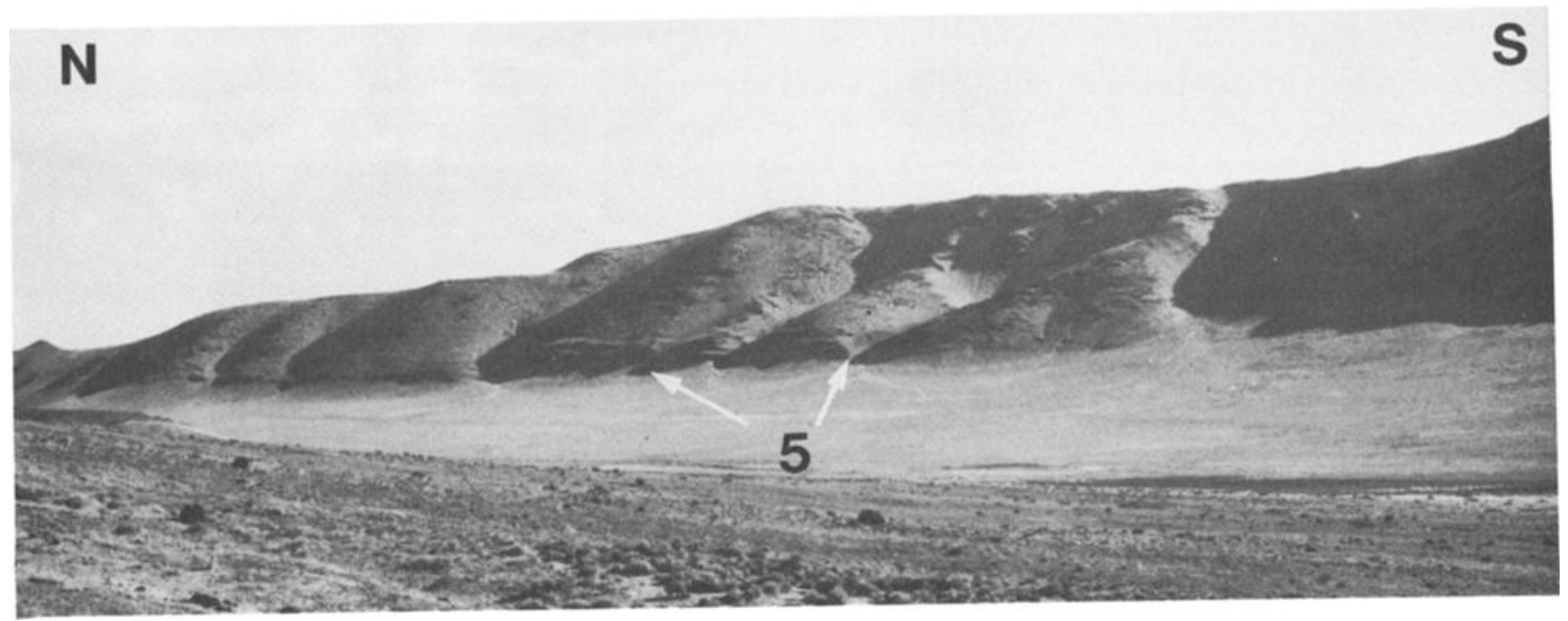

Figure 9. View looking northeast of the eastern Dry Valley fault scarp. Arrows point to the fault slip measurement sites (site 5; see Table 2 for location). 


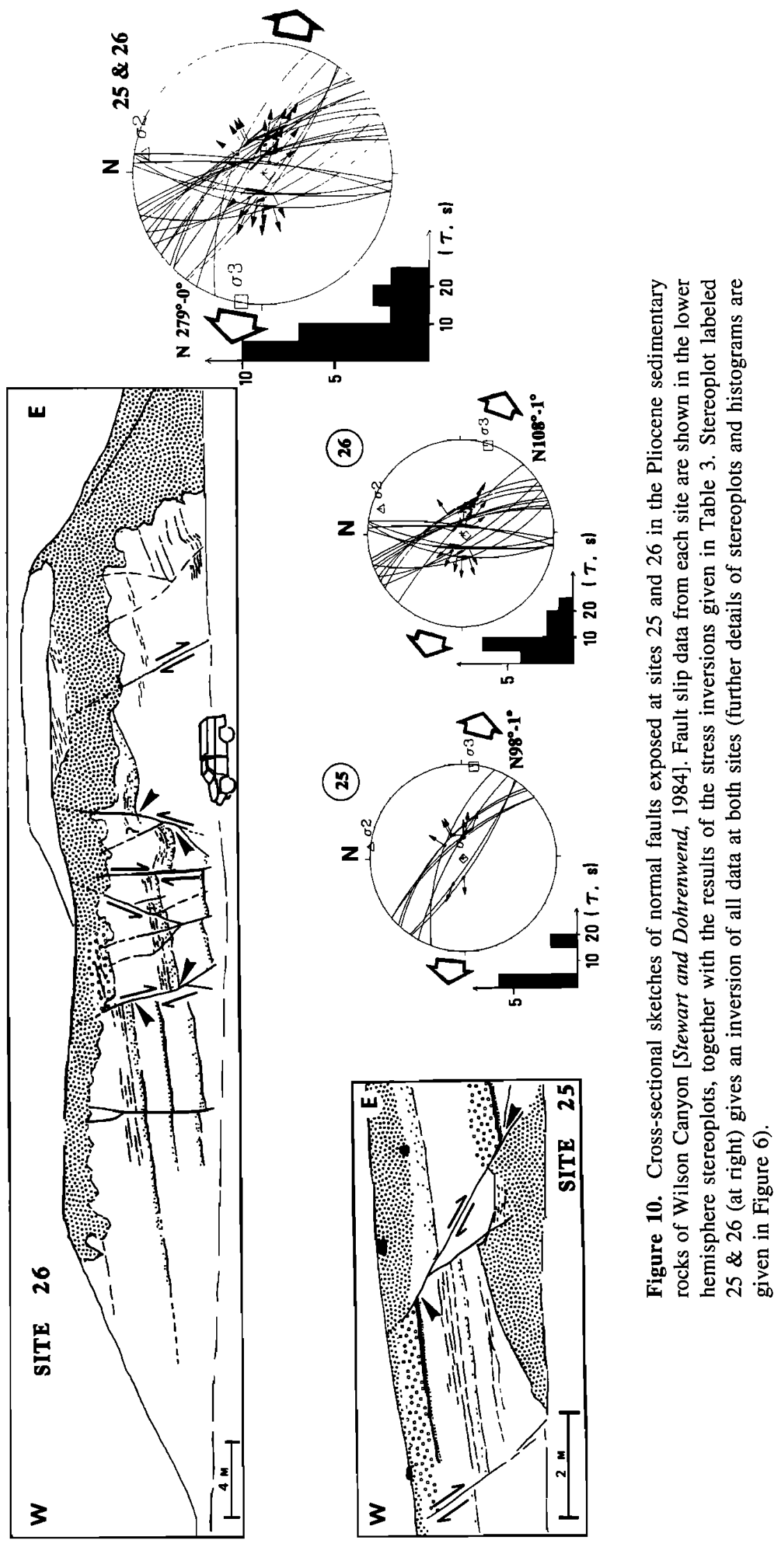




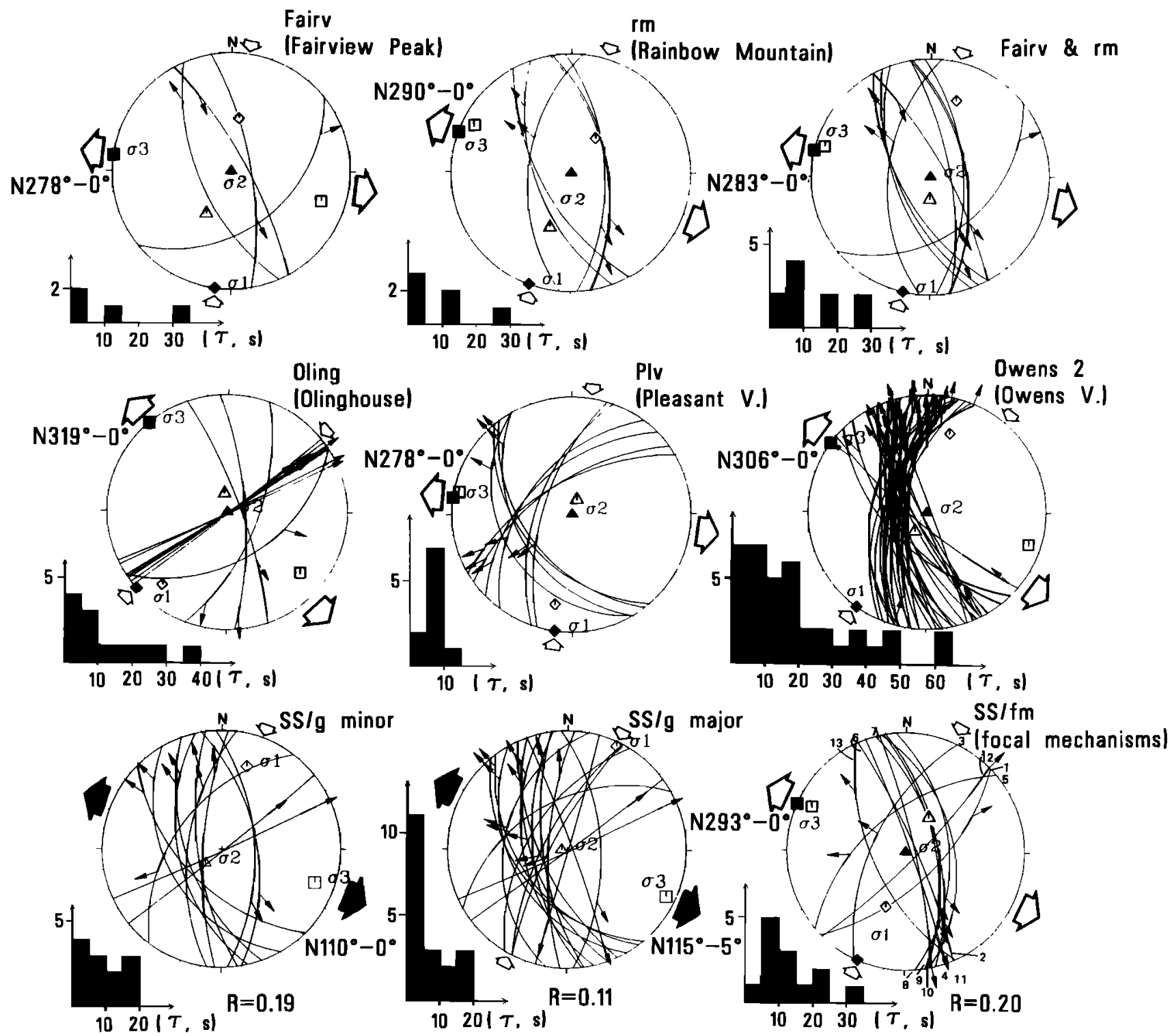

Figure 11. Lower hemisphere stereoplots of strike-slip faulting slip data from the Walker Lane region, together with inversion results presented in Table 4. Labels outside and to top right of the stereoplots refer to site names and numbers shown in Figure 1 and described in Table 2. (See Figure 6 for a detailed explanation of the stereoplots and histograms.) Also given are stereoplots showing the data and inversion results for three combined "regional" data sets listed in Table 4. Abbreviations include SS/g-major, combination of all strikeslip data measured on major faults at all five sites; SS/g-minor, combination of all slip data measured on more significant minor faults at each of the five sites; and SS/fm, inversion of the best constrained fault planes and slip vectors for historic earthquakes. The individual fault planes and slip data shown on SS/fm come from Table 5; the fault numbers on this stereoplot refer to the numbers in the second column of Table 5.

right-lateral oblique-slip to normal dip-slip faults. The historic faults are, from north to south (see Figure 1); the 1915 Pleasant Valley, the 1954 Dixie Valley, the 1954 Rainbow Mountain, the 1903 Wonder, the 1954 Fairview Peak, the 1932 Cedar Mountain, the 1986 Chalfant Valley, the 1980 Mammoth Lakes, and the 1872 Owens Valley faults. Geological field data and focal mechanisms [e.g., Doser, 1986, 1988; Zoback, 1989; dePolo et al., 1989, 1991] indicate that the style of slip in these earthquakes along the
Nevada Seismic Belt varies from predominantly normal dip slip in the northern part of the zone (the Pleasant Valley fault) to oblique right-lateral slip in the central part of the zone (Dixie Valley/Fairview Peak/Rainbow Mountain faults) to nearly pure right-lateral strike-slip events in the southernmost part of the seismic belt (Chalfant Valley and Owens Valley faults).

In addition, several other historic earthquakes have occurred in the WLZ with sparsely distributed surface faulting. These 
Table 4. Results of Stress Tensor Inversion for Slip Data Representing Strike-Slip Faulting Stress Regime

\begin{tabular}{|c|c|c|c|c|c|c|c|c|c|}
\hline \multirow[b]{2}{*}{ Site } & \multirow[b]{2}{*}{$\mathbf{N}$} & \multicolumn{3}{|c|}{ Azimuth/Plunge, deg } & \multirow[b]{2}{*}{ M.D. } & \multirow[b]{2}{*}{ S.D. } & \multirow[b]{2}{*}{$\mathbf{R}$} & \multirow[b]{2}{*}{ Age } & \multirow[b]{2}{*}{ Qual } \\
\hline & & $\sigma_{1}$ & $\sigma_{2}$ & $\sigma_{3}$ & & & & & \\
\hline \multicolumn{10}{|c|}{ Pleasant Valley Fault } \\
\hline plv & 10 & $191 / 14$ & $017 / 76$ & $281 / 02$ & 04.6 & 05.6 & 0.40 & $\mathrm{eMz}$ & - \\
\hline plv & 10 & $188 / 00$ & $042 / 90$ & $278 / 00$ & 06.7 & 07.2 & 0.33 & $\mathrm{eMz}$ & * \\
\hline \multicolumn{10}{|c|}{ Fairview Peak and Rainbow Mountain Faults } \\
\hline fairv & 04 & $007 / 41$ & $212 / 47$ & $108 / 13$ & 04.1 & 05.2 & 0.70 & $\mathrm{mM}+\mathrm{lM}$ & - \\
\hline fairv & 04 & $188 / 00$ & $041 / 90$ & $278 / 00$ & 11.7 & 16.1 & 0.33 & $\mathrm{mM}+\mathrm{lM}$ & * \\
\hline $\mathrm{rm}$ & 06 & $033 / 52$ & $199 / 37$ & $294 / 07$ & 09.3 & 10.3 & 0.23 & $\mathrm{mM}-1 \mathrm{M}$ & - \\
\hline $\mathrm{rm}$ & 06 & $200 / 00$ & $065 / 90$ & $290 / 00$ & 10.3 & 14.4 & 0.20 & mM-1M & $*$ \\
\hline fairv \& rm & 10 & $016 / 21$ & $185 / 68$ & $285 / 04$ & 11.5 & 14.4 & 0.31 & $10+M$ & - \\
\hline fairv \& rm & 10 & $193 / 00$ & $050 / 90$ & $283 / 00$ & 12.8 & 16.0 & 0.32 & $10+M$ & * \\
\hline \multicolumn{10}{|c|}{ Olinghouse Fault } \\
\hline oling & 12 & $222 / 11$ & $352 / 74$ & $129 / 12$ & 09.6 & 12.9 & 0.50 & $\mathrm{mP}-\mathrm{lP}$ & - \\
\hline oling & 12 & $229 / 00$ & $094 / 90$ & $319 / 00$ & 12.4 & 16.2 & 0.00 & $\mathrm{mP}-\mathrm{lP}$ & * \\
\hline \multicolumn{10}{|c|}{ Owens Valley Fault } \\
\hline owens 2 & 37 & $016 / 20$ & $212 / 70$ & $108 / 05$ & 12.1 & 16.2 & 0.96 & $\mathrm{Pl}$ & - \\
\hline owens 2 & 37 & $216 / 00$ & $106 / 90$ & $306 / 00$ & 18.9 & 24.9 & 0.32 & $\mathrm{Pl}$ & * \\
\hline \multicolumn{10}{|c|}{ Regional Results } \\
\hline $\mathrm{SS} / \mathrm{GEO}^{\mathrm{a}}$ & & $21 \pm 17 / 08$ & & $11 \pm 11 / 01$ & & & 0.25 & & \\
\hline SS/g-minor ${ }^{b}$ & 12 & $017 / 18$ & $229 / 70$ & $110 / 10$ & 08.4 & 10.1 & 0.19 & $M z-Q$ & + \\
\hline SS/g-major ${ }^{c}$ & 19 & $025 / 02$ & $272 / 85$ & $115 / 05$ & 05.7 & 08.3 & 0.11 & $\mathrm{Mz}-\mathrm{Q}$ & + \\
\hline $\mathrm{SS} / \mathrm{fm}^{\mathrm{d}}$ & 13 & $199 / 38$ & 034.51 & $295 / 07$ & 10.8 & 13.7 & 0.28 & Historic & - \\
\hline SS/fm ${ }^{d}$ & 13 & $203 / 00$ & $056 / 90$ & $293 / 00$ & 13.5 & 16.0 & 0.20 & Historic & $*$ \\
\hline
\end{tabular}

Description of individual columns same as in Table 3. Note that plv represents inversion of strike-slip stiae measured along the Pleasant Valley fault zone (plv1 to plv5).

a SS/GEO is the mean regional horizontal deviatoric stress axes determined using Fisher statistics independently on the two subhorizontal stress axes from each of the individual inversions, arithmetic mean $R$ value computed only from fixed inversion results (* in Qual column).

bSS/g-minor is an inversion of all slip data measured on minor faults adjacent to the main fault zone at each of the five sites.

c SS/g-major is an inversion of all slip data measured on the major faults zones at each of the sites.

d SS/fm is an inversion of historic fault slip along the Nevada Seismic Belt and adjacent parts of the Walker Lane zone computed using parameters for historic fault slip reported in Table 5 and shown in Figure 12, both poorlyconstrained $(-)$ and fixed inversion $(*)$ results given.

distributed surface ruptures include the ENE trending Olinghouse and Excelsior Mountain faults, the north trending Fort Sage Mountain fault, and the NE trending Truckee fault (Figure 1). The historic slip in these earthquakes was a combination of right-lateral and normal faulting on NNW to NNE trending faults and predominantly left-lateral to normal faulting on ENE to WNW trending faults. We have tabulated in Table 5 all the available information on slip vectors for these historic events.

Seismic activity has also been intense in the Mammoth Lake/Long Valley caldera region just south of Mono Lake. In addition to a May 25, 1980, $M=6.3$ earthquake near Mammoth Lake, swarmlike sequences of several $(M>5)$ earthquakes occurred in October 1978 and May 1980 in the Mammoth Lake region [Ryall and Ryall, 1981a,b; Hill et al., 1985]. Most focal mechanisms obtained for these earthquakes show a mean $\mathrm{N} 65^{\circ} \mathrm{E}$ trending $\mathrm{T}$ (tension) axis, nearly $40^{\circ}$ to $50^{\circ}$ oblique to $\mathrm{T}$ axes of earthquakes in the surrounding region [Lide and Ryall, 1985; Vetter and Ryall, 1983; Vetter, 1990]. Deformation in the Mammoth Lake and Long Valley caldera region appears to be a local anomaly in the regional stress pattern and is possibly related to active magmatic resurgence superimposed on regional extension of the Basin and Range province [Hill et al., 1985; Moos and Zoback, 1993]. For this reason, we have not included focal mechanisms of any of the Mammoth Lake earthquakes within this present-day state of stress study.

The available slip vectors for the historic earthquakes along the Nevada Seismic Belt and within the WLZ deduced from published focal mechanisms or from analyses of geological surface rupture are given in Table 5 and are plotted on the stereonet SS/fm in Figure 11. The inferred, contemporary mean stress state deduced from a standard inversion of these data is a strike-slip stress regime characterized by subhorizontal $N 65^{\circ} \mathrm{W}$ trending $\sigma_{3}\left(\sigma_{h \min }\right)$ axis, with $\sigma_{1}$ and $\sigma_{2}$ lying in a well-constrained plane perpendicular to this direction, and with $\sigma_{2}$ having the steepest plunge (51 $51^{\circ}$ toward the NE) (Figure 12 and Table 4). An $R$ value of 0.28 for this $\mathrm{SS} / \mathrm{fm}$ inversion indicates a stress state where $\sigma_{1}$ is close in magnitude to $\sigma_{2}$, explaining the clear definition of the $\sigma_{1}-\sigma_{2}$ plane but not the unique definition of the individual axes. An inversion fixing one of the principal stresses to be vertical yielded a $\sigma_{3}$ axis trending only $2^{\circ}$ differently and a similar $R$ value $(R=0.20)$ confirming that the present-day strike-slip stress state is very close to transitional between the strikeslip and normal faulting stress regimes.

In conclusion, a recent strike-slip stress regime along the 


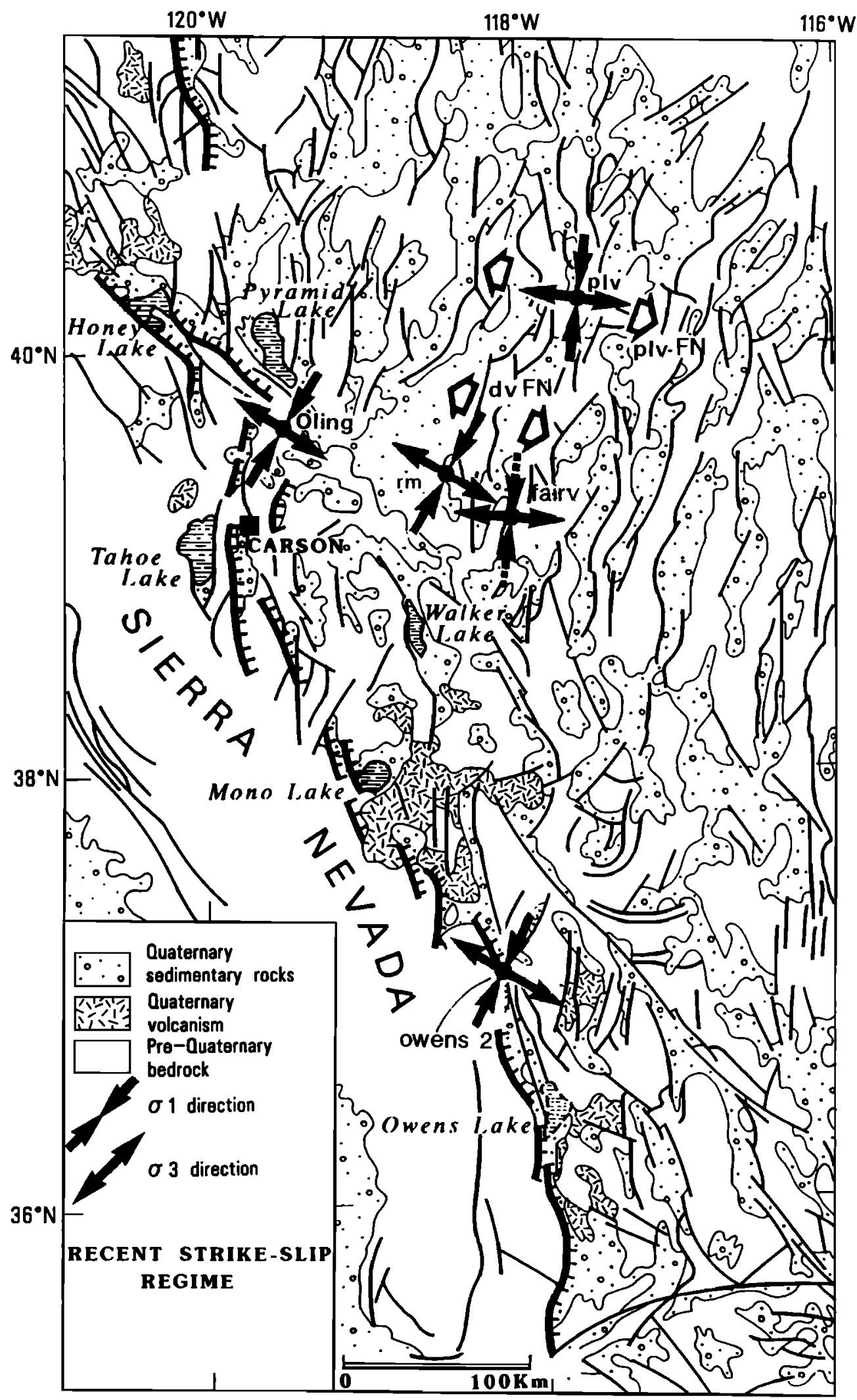

Figure 12. Azimuths of $\sigma_{1}$ (maximum horizontal stress) and $\sigma_{3}$ (least horizontal stress) axes for the strikeslip stress regime deduced from the individual fault slip inversions given in Table 4. Large, open arrows, representing the $\sigma_{3}$ (least horizontal stress) axes determined from the normal fault slip inversions along the Pleasant Valley and Dixie Valley fault zones (from Table 3), are given for comparison. 
Table 5. Seismic Fault Slip From Historical Earthquakes

\begin{tabular}{|c|c|c|c|c|c|c|c|c|}
\hline \multirow[t]{2}{*}{ Fault } & \multirow{2}{*}{$\begin{array}{c}\text { Fault } \\
\text { Number a }\end{array}$} & \multirow[t]{2}{*}{ Date } & \multirow[t]{2}{*}{ Magnitude } & \multicolumn{3}{|c|}{ Fault Plane ${ }^{b}$} & \multirow[t]{2}{*}{ Method ${ }^{\mathrm{c}}$} & \multirow[t]{2}{*}{ Reference $^{\mathrm{d}}$} \\
\hline & & & & $\begin{array}{c}\text { Strike } \\
\text { deg }\end{array}$ & $\begin{array}{l}\text { Dip } \\
\text { deg }\end{array}$ & $\begin{array}{c}\begin{array}{c}\text { Rake } \\
\text { deg }\end{array} \\
\end{array}$ & & \\
\hline Olinghouse & 1 & Dec. 27,1869 & $M l 6.7$ & 45 & 60 & -30 & $\mathrm{G}$ & 1,2 \\
\hline Owens Valley & 2 & March 26, 1872 & $M w 7.25-8$ & 160 & 85 & -170 & $\mathrm{G}$ & 3 \\
\hline Owens Valley & & March 26, 1972 & $M w 7.25-8$ & 195 & 89 & -160 & $\mathrm{G}$ & 3 \\
\hline Wonder & & $1903 ?$ & $M l$ 5.5-6.5 & N-S & & & G & 4 \\
\hline Pleasant Valley & 3 & Oct. 2,1915 & $M s 7.6$ & 25 & 59 & -94 & G & 5,6 \\
\hline Pleasant Valley & & Oct. 2,1915 & $M s 7.6$ & 14 & 44 & -119 & FM & 7 \\
\hline Cedar Mountain & & Dec. 21,1932 & $M l 7.2$ & 181 & 72 & -176 & FM & $7,8,9$ \\
\hline Cedar Mountain & 4 & Dec. 21,1932 & $M l 7.2$ & 167 & 81 & -179 & FM & 7 \\
\hline Excelsior Mtn. & 5 & Jan. 30,1934 & $M l 6.3$ & 49 & 54 & -53 & FM & $7,10,11$ \\
\hline Excelsior Mtn. & & Jan. 30,1934 & $M l 6.3$ & 68 & 40 & -90 & FM & 7 \\
\hline Fort Sage & & Dec. 14,1950 & $M l 5.6$ & $\mathrm{~N}-\mathrm{S}$ & & & $\mathbf{G}$ & $5,12,13$ \\
\hline Rainbow Mtn. & 6 & June 6,1954 & $M w 6.2$ & 156 & 80 & -140 & FM & $4,5,14,15$ \\
\hline Rainbow Mtn.-1 & & June 6,1954 & $M w 6.2$ & 160 & 60 & -115 & FM & 14 \\
\hline Rainbow Mtn.-2 & 7 & June 6,1954 & $M w 5.9$ & 165 & 60 & -135 & FM & 14 \\
\hline Rainbow Mtn.-3 & 8 & Aug. 24, 1954 & $M w 6.5$ & 175 & 50 & -125 & FM & $4,5,14,15$ \\
\hline Fairview Peak & 9 & Dec. 16,1954 & $M w 6.9$ & 170 & 60 & -160 & FM & $4,5,14,15$ \\
\hline Dixie Valley & & Dec. 16,1954 & $M w 6.7$ & 170 & 50 & -90 & FM & $14-17$ \\
\hline Dixie Valley & 10 & Dec. 16,1954 & $M w 6.7$ & 169 & 62 & -152 & FM & 18 \\
\hline Dixie Valley & 11 & March 23, 1959 & $M s 6.3 ?$ & 168 & 46 & -168 & FM & 14 \\
\hline Truckee & 12 & Sept. 12, 1966 & $M s 5.7$ & 224 & 80 & -1 & FM & 19,20 \\
\hline Mammoth Lake & & May 25,1980 & $M l 6.3$ & & & & FM & $21,22,23$ \\
\hline Chalfant Valley & & July 21,1986 & $M s 6.2$ & 335 & 60 & -179 & FM & 24 \\
\hline Chalfant Valley & 13 & July 21,1986 & $M s 6.2$ & 335 & 59 & -152 & FM & 25,26 \\
\hline
\end{tabular}

a Fault numbers refer to the stereoplot in Figure 12. Where two fault slip parameters are given for the same earthquake, the numbered fault parameters are considered to be the best determined and are used in the inversion. The result of standard and fixed inversions of this data set are given as solution SS/fm in Table 4.

b Fault plane slip vectors are specified by strike, dip, and rake using standard seismological convention. Strike azimuth measured clockwise from north, $90^{\circ}$ less than dip direction; dip measured from horizontal; and rake gives the direction of motion of the hanging wall with respect to the footwall measured counterclockwise from the strike direction (positive rakes indicate thrust faulting, negative rakes indicate normal faulting, rakes with absolute values $<90^{\circ}$ are left-lateral, rakes with absolute values $>90^{\circ}$ are right-lateral).

${ }^{c}$ Method indicates how the mean slip vector was determined; $G$, determined geologically from surface rupture and displacements and FM, determined from an earthquake focal mechanism where the fault plane was selected using the surface fault trace.

d References are as follows: 1, Slemmons [1977]; 2, Sanders and Slemmons [1979]; 3, Beanland and Clark [1995]; 4, Slemmons et al. [1959]; 5, Bonilla et al. [1984]; 6, Wallace [1984b]; 7, Doser [1988]; 8, dePolo et al. [1987, 1989, 1991]; 9, Molinari [1984]; 10, Ryall and Priestley [1975]; 11, Slemmons et al. [1965]; 12, Gianella and Callahan [1934]; 13, Gianella [1957]; 14, Doser [1986]; 15, Slemmons [1957]; 16, Bell and Katzer [1990]; 17, Zoback [1989]; 18, Romney [1957]; 19, Ryall et al. 1966]; 20, Tsai and Aki [1970]; 21, Ryall and Ryall [1981a]; 22, Hill et al. [1985]; 23, Clark et al. [1982]; 24, Cockerham and Corbett [1987]; 25, Gross and Savage [1987]; 26, Lienkaemper et al. [1987] and dePolo and Ramelli [1987].

Nevada Seismic Belt and within the WLZ has been demonstrated by fault slip inversions on both the youngest geologically measured striae and inferred earthquake slip vectors. All inversions suggest that the present-day state of stress is a strike-slip stress regime close to transitional to a normal faulting stress regime (low $R$ value), explaining the compatibility between the observed normal, oblique, and strike-slip active faulting. Even the geologically determined, dominantly normal slip (rake $=86^{\circ}$ ) in the 1915 Pleasant Valley earthquake is compatible with this strike-slip stress tensor because the mean fault trend is approximately perpendicular to the $\sigma_{3}\left(\sigma_{h m i n}\right)$ direction. As discussed in the beginning of the Results section, slip-vector chronologies on fault planes cutting recent deposits suggest a recent change from a normal to a strike-slip faulting in stress regime with a consistent WNW trending $\sigma_{3}\left(\sigma_{h \min }\right)$ axis, supporting results of a previous analysis of well-constrained major fault offsets in Owens Valley by Zoback [1989]. Whether there is one, single change in stress regime, or fluctuations or temporal variations in stress regime, can not be resolved with the existing data.

\section{Explanations for Slip on Subparallel Strike-Slip and Normal Faults}

Wright [1976] explained the complex interaction of active strike-slip, oblique, and normal dip-slip faulting within the WLZ as a simple consequence of a single stress state, one transitional between strike-slip and normal faulting $\left(\sigma_{H \text { max }} \approx\right.$ $\sigma_{V}$, or $R \approx 0$ in both regimes) with minor local fluctuations. However, as summarized by the data presented above, while the WNW orientation of the least principal axis appears to 
remain approximately constant, substantial changes in relative stress magnitudes are required to explain the observed deformation in this region. The contemporary stress field in the WLZ does appear to be characterized by a strike-slip stress regime transitional to normal faulting (with $R=0.1-0.2$ ); however, this stress state is incompatible with the slip data from the best constrained normal fault inversions (which require a normal faulting stress regime with $R \approx 0.7$ ) as well as with the observations of crosscutting striae with highly oblique rakes $\left(65^{\circ} \pm 15^{\circ}\right)$ observed on several fault planes. These data suggest temporal changes in stress regime in the WLZ and, specifically, a recent change (possibly post late Pleistocene and pre-Holocene based on the crosscutting striae in Owens Valley) from a dominantly normal faulting regime to a strike-slip regime. These results are consistent with conclusions based on a previous analysis of large-scale late Pleistocene fault offsets in the Owens Valley region which indicate a relatively recent (post-300,000 year, pre-10,000 year) change from a normal faulting stress regime with a high $R$ value to a strike-slip faulting regime with a low $R$ value [Zoback, 1989]. The change from a normal to a strike-slip faulting stress regime can be interpreted in terms of a temporal and/or lateral variation in the magnitude of one or more of the stresses.

Recently, Wesnousky and Jones [1994] suggested that the combined normal and strike-slip deformation in the Owens Valley and surrounding WLZ can be explained simply as a consequence of strain partitioning of dip-slip and strike-slip displacement on subparallel normal and strike-slip faults within a single regional stress state (provided there are marked differences in the frictional strength of the dip-slip and strikeslip faults). They argued that the shallow rakes (strike-slip movement) inferred for the steeply-dipping Owens Valley fault zone could also be compatible with a number of stress states which would also permit the observed dip-slip movement on the Independence fault (within the uncertainities of published data) by correctly point out a problem with the stress analysis based on slip on only these two faults: for horizontal and vertical stress axes, a near-vertical fault $\left(90^{\circ} \pm 5^{\circ}\right)$ will always exhibit nearly pure strike-slip motion, regardless of the stress regime or $R$ value, as long as there is shear stress in the horizontal plane (that is, $\sigma_{H \max } \neq \sigma_{\text {hmin }}$ ). However, we think that the crosscutting strike-slip and normal fault striae reported here on the same fault planes with moderate dips (dips between $40^{\circ}$ and $58^{\circ}$ in Owens Valley and between $56^{\circ}$ and $59^{\circ}$ along the Rainbow Mountain fault zone) support the earlier conclusion of temporal variations in stress regime, rather than simple strain partitioning within a single regional stress field. However, the concept of strain partitioning is currently being widely discussed and its relationship to regional stress state deserve more discussion.

The combined strike-slip and thrust deformation on subparallel faults within the San Andreas fault system could be viewed as an analog to deformation in the WLZ. Extensive stress studies [Mount and Suppe, 1987, 1992; Zoback et al., 1987; Oppenheimer et al., 1988] indicate that the strain partitioning along the San Andreas fault system and also adjacent to the similar Great Sumatran right-lateral strike-slip fault (in an oblique subduction environment [see Mount and Suppe, 1992]) occur in response to a uniform regional stress field, one in which $\sigma_{H \max }$ is oriented nearly perpendicular (80$85^{\circ}$ ) to the strike of the main strike-slip fault. In both areas a small component of right-lateral shear allows the "weak" strike-slip fault to slip, while the normal component of plate motion is accommodated on subparallel thrusts. In fact, Zoback et al. [1987] have argued that the regional approximately fault-normal orientation of $\sigma_{\operatorname{Hax}}$ in an $\sim 100$ $\mathrm{km}$-wide zone on both sides of the plate boundary in California is a consequence of the very low shear strength of the main San Andreas fault zone; the stress rotation occurring because the San Andreas fault zone is nearly a principal stress plane, thus, the shear stress across it must be reduced. Hence, while the strain field is partitioned to dip-slip movement on dipping faults and strike-slip motion on subparallel vertical faults, the stress field responsible for both sets of slip appears uniform.

In the context of these discussions of the San Andreas fault, it is clear that strain partitioning within a uniform stress model requires marked variations in the relative shear strength of vertical strike-slip and subparallel dipping faults. Wesnousky and Jones' analysis suggests that the Independence normal fault zone in Owens Valley must be at least 4 times stronger than a vertical Owens Valley strike-slip fault (their figure 3). Unlike the many papers written about the absolute and relative weakness of major plate-boundary faults like the San Andreas fault, Wesnousky and Jones simply assume the weakness of the strike-slip Owens Valley fault relative to the Independence fault without presenting any evidence to support this assumption. This assumption requires that the discontinous strike-slip faults within the WLZ are much weaker than the major, subparallel, continuous Sierra Nevada frontal fault system. Thus in rejecting possible temporal variations in the stress field to explain deformation in the WLZ, Wesnousky and Jones [1994] offer a "simpler" hypothesis of strain partitioning that requires marked differences of the strength of faults without any independent substantiating evidence.

Considering the concept of strain partitioning in general, it could be assumed that the Sierran frontal normal fault system is a weak fault controlling the stress field. However, the observed nearly pure dip-slip movement on this fault would require little or no shear stress in the horizontal plane and/or an $\sigma_{H \max }$ oriented subparallel to the Sierran frontal fault $(\sim N N W)$. Neither case would be conducive to slip on the subparallel Owens Valley fault zone, requiring that the strikeslip fault would also have to be weak in order to slip!

Inversion of the slip data presented here as well as the alignment of young volcanic vents suggest a NNE to north trending $\sigma_{\text {Hmax }}$ orientation in this region (not NNW); the nearly pure dip-slip movement on the NNW trending frontal fault requires a normal faulting stress regime in which the two horizontal stresses are approximately equal $(R \approx 1.0)$. The north to NNE $\sigma_{\text {Hmax }}$ orientation is compatible with activation of the NNW trending Owens Valley strike-slip fault zone; however, a change in relative stress magnitudes is required in order to have enough horizontal shear stress to drive the strike-slip faulting. That is, while the orientation of the principal stress axes remains constant, the apparently younger dominantly strike-slip deformation on subparallel faults occurs in a stress regime transitional between strike-slip and normal faulting $\left(\sigma_{H \max } \approx \sigma_{h \min }\right.$ or $\left.R \approx 0.1-0.2\right)$. 
Table 6. Angular Difference Between Measured and Predicted Slip Vectors on Owens Valley Fault

\begin{tabular}{lccccc}
\hline \multicolumn{1}{c}{ Fault Data } & SS/g-major, deg & SS/g-minor, deg & SS/GEO, deg & SS/fm, deg & NF/GEO, deg \\
\hline 1872 slip & 0 & 3 & 8 & 7 & 40 \\
2.2 (younger) & 15 & 14 & 17 & 18 & 72 \\
2.1 (older) & 61 & 62 & 58 & 58 & 4 \\
\hline
\end{tabular}

Values are the deviation angles (the difference between predicted $\tau$ and measured $s$ slip vectors) for the various regional stress states indicated, NF stress state from Table 3, SS stress states from Table 4. See text for discussion of significance of results presented here.

Previously mentioned crosscutting dip-slip and strike-slip striae are further evidence of variations in relative stress magnitudes within this actively deforming region. Striae sets 2.1 and 2.2 (Figure 3 ) were measured on a minor fault in a $<300,000$-year-old basalt flow adjacent to the Owens Valley fault zone and are an excellent example of very young changes in slip on the same fault plane. To quantitatively test whether these slip data or the slip in the 1872 Owens Valley earthquake (from Table 5) could be explained by strain partioning in a single regional stress field, we computed predicted slip vectors on these fault planes using the regionally significant strikeslip stress states (SS/g-major, SS/g-minor, SS/GEO and $\mathrm{SS} / \mathrm{fm}$ ) as well as the "earlier" normal faulting (NF/GEO) stress state determined in this paper. The deviation angles between the predicted and observed slip are tabulated in Table 6. Note that the deviation angles for the most recent deformation (Owens Valley earthquake and striae set 2.2) are very consistent with the computed regional strike-slip stress states (deviation angles between $0^{\circ}$ and $18^{\circ}$ ) and are incompatible with the "older" normal faulting stress regime (deviation angles between $40^{\circ}$ and $72^{\circ}$ ). In contrast, the slip represented by the older striae set, 2.1 , is well predicated by the normal fault stress state (deviation angle $=4^{\circ}$ ) and is incompatible with the strike-slip stress states (deviation angles $=60^{\circ} \pm 2^{\circ}$ ). These results suggest that the deformation along the Owens Valley fault zone can not be explained by strain partitioning within a single regional stress field; the normal dip slip movement appears related to a normal faulting stress regime, while the strike-slip faulting is compatible with a recent strike-slip faulting stress regime.

The postulated change in stress regime from a normal faulting regime with $R \approx 0.75-1.0$ to a strike-slip regime with $R=0.1-0.2$ could be accomplished by a temporal variation in the magnitude of the maximum horizontal stress $\left(\sigma_{\mathrm{NNE}}\right)$. To demonstrate how different these two stress states are, we can examine changes in the magnitude of the maximum horizontal stress required by the "frictional strength of optimallyoriented faults" model to predict crustal stresses at depth [Jaeger and Cook, 1979, p. 80]) :

$$
\left(\sigma_{1}-P\right) /\left(\sigma_{3}-P\right)=\left[\left(\mu^{2}+1\right)^{1 / 2}+\mu\right]^{2}
$$

where $P$ is pore pressure, and $\mu$ is the sliding frictional coefficient on the most well-oriented faults assumed to control frictional strength. Using $\mu=0.65$ as a typical value of crustal friction (Byerlee's law [Byerlee, 1978]) and assuming hydrostatic pore pressure $\left(P=(1 / 2.67) \sigma_{V}=0.3737 \sigma_{V}\right), \sigma_{1} / \sigma_{3}$ values can be computed. Assuming the vertical principal stress is equal to the lithostat ( $\rho \mathrm{gz}$ ) and utilizing mean $R$ values for the two regimes $(R=0.15$ in strike-slip regime, $R=0.75$ for normal faulting regime), we calculated the predicted effective stress magnitudes. Because the two stress states have the same principal axis directions (coaxial), they can be easily represented on the same Mohr's circle. The stress values shown on the Mohr's circle in Figure 13 correspond to $7.5 \mathrm{~km}$ depth, roughly half the thickness of the brittle layer in the Basin and Range as defined by seismicity, and hence they should represent approximate mean stress values within the brittle layer. As is clear on the Mohr's circle, the primary difference between the two regimes is a roughly $80 \mathrm{MPa}$ difference in the relative magnitude of the maximum horizontal effective stress $\left(\sigma_{\mathrm{NNE}^{-}} P\right.$. which is $\sigma_{1}$ in the strikeslip regime, $\sigma_{2}$ in the normal faulting regime).

The source of either a lateral or temporal variation in $\sigma_{\mathrm{NNE}}$ $\left(\sigma_{\text {Hax }}\right)$ magnitude is enigmatic. As Zoback [1989] pointed out, tectonic processes related to the Sierra Nevada-Basin and Range boundary zone such as stress effects due to the abrupt and high topography of the Sierra or shear tractions due to the lateral contrast in crust/lithosphere structure and/or heat flow should primarily affect the magnitude of the WNW horizontal stress $\left(\sigma_{3}\right)$. The $\sim 80 \mathrm{MPa}$ difference in $\sigma_{\mathrm{NNE}}$ magnitudes between the two regimes is much greater than the stress change associated with an individual large earthquake in the

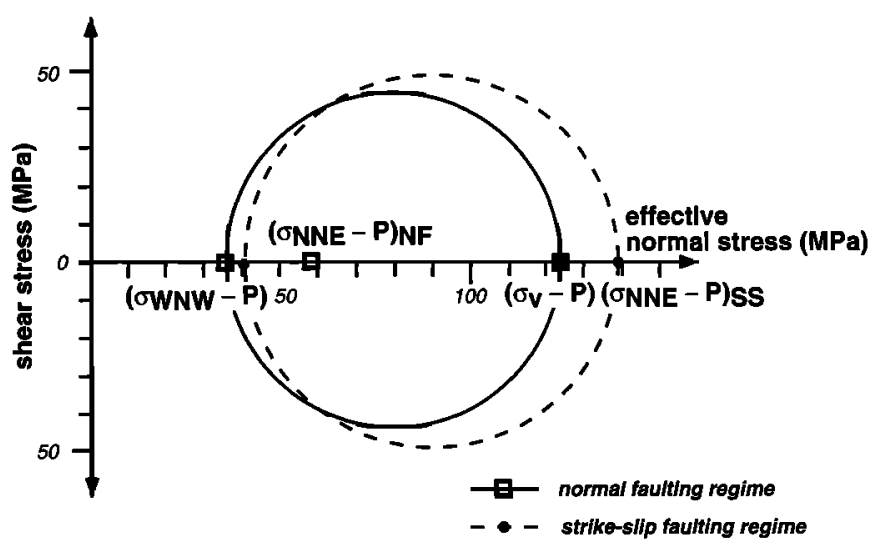

Figure 13. Mohr's circle representation of effective stress states $(\sigma-P)$ for the two coaxial stress regimes determined for the WLZ; the normal faulting stress regime $(R=0.15)$ is represented by the solid circle, and the strike-slip stress regime $(R=0.75)$ is given by the dashed circle. In both regimes the minimum horizontal stress is $\sigma_{3}$ and is given by $\sigma_{W N W}$; the maximum horizontal stress is given by $\sigma_{\mathrm{NNE}}$; and the vertical stress is given by $\sigma_{v}$ (equals $\sigma_{2}$ in the strike-slip case, $\sigma_{1}$ in the normal faulting case). Stress magnitudes determined using the frictional strength of optimally oriented faults model to predict crustal stresses at depth (see text). Note that the primary difference between the two stress states can be explained by a relative change in the maximum horizontal effective stress $\left(\sigma_{\mathrm{NNE}}-P\right)$ of $\sim 80 \mathrm{MPa}$. 
region (earthquake stress drops are typically of the order of 0.1-10 MPa [Thatcher and Hanks, 1973]). The differences in stress magnitude between the two regimes could be much smaller in the case of elevated pore pressure in the source region which would reduce the overall stress differences $\left(\sigma_{1-}\right.$ $\sigma_{3}$ ) required to cause faulting [e.g., Zoback, 1992].

Unfortunately, the timing of the temporal variations in stress state inferred from the geologic data is too poor to determine if there has been a single recent absolute change in stress magnitude or if this variation is fluctuating or cyclical. Stewart [1992] noted that strike-slip deformation has occurred in the WLZ throughout the late Tertiary, as well during the Mesozic when the faulting may have begun as intra-arc or back arc strike-slip faults. He also points out that the present-day WLZ is largely coextensive with the Miocene (20-24 Ma) magmatic arc and attributes much of the pre-5.5 m.y. old shear deformation in the WLZ to intra-arc strike-slip faulting subparallel to the active offshore obliquely convergent subduction zone, a style of deformation observed in a number of present-day analogs [e.g., Fitch, 1972; Beck, 1983; Jarrard, 1986; McCaffrey, 1991; Beck et al., 1993]. Thus deformation in easternmost California and westernmost Nevada appears to have accommodated a portion of the relative plate motion along the western plate boundary throughout much of the late Tertiary and possibly since the Mesozoic.

The existence of a present-day NNW trending zone of rightlateral shear extending northward from the San Andreas fault in the south through the eastern Mojave Desert and up into Owens Valley carrying $-8 \mathrm{~mm} / \mathrm{yr}$ of relative plate motion has been suggested on the basis of geologic and geodetic data [Bird and Rosenstock, 1984; Sauber et al., 1986; Dokka and Travis, 1990a, 1990b; Savage et al., 1990] and recently by Ward [1990] using very long baseline interferometry (VLBI) measurements. Dokka and Travis [1990b] suggest that this eastern California shear zone has carried between $18 \%$ and 23\% of Pacific-North American plate motion over the last 5.5 m.y. and they further suggest that this intracontinental shear may continue to the north and include the Walker Lane zone. These observations all suggest a link between deformation along the southernmost part of the Nevada Seismic Belt within the WLZ and broad-scale San Andreas plate motion deformation.

\section{Conclusions}

Late Cenozoic tectonics in the WLZ are characterized by normal, oblique, and strike-slip faulting which reactivated inherited Mesozoic structures and produced new faults. Inversion of fault slip data collected along both major and minor fault zones indicate two Plio-Quaternary stress states. A normal faulting stress regime with a mean $\sigma_{3}$ axis of $N 83^{\circ} \mathrm{W}$ and a mean $R$ value $\left(R=\left(\sigma_{2}-\sigma_{1}\right) /\left(\sigma_{3}-\sigma_{1}\right)\right)$ of $0.63-0.74$ appears to have been replaced in much of the region by a younger strike-slip faulting stress regime with a $\sigma_{3}$ axis of $N 65-70^{\circ} \mathrm{W}$ and a mean $R$ value of $0.1-0.2$. This younger strike-slip stress state is close to transitional to normal faulting and is consistent with focal mechanisms of the historic earthquakes in the WLZ. Previous workers have explained all the complex patterns of strike-slip, oblique, and normal faulting in the WLZ as a simple consequence of minor fluctuations about a such single transitional stress state (with a WNW trending $\sigma_{3}$ axis and with the maximum horizontal stress approximately equal to vertical stress, or $R \approx 0$ in both regimes). However, such a stress state is not consistent with observed postPleistocene, nearly pure dip-slip movement on the Sierran frontal fault zone. An alternative, strain-partitioning model has been proposed to explain slip on the subparallel strikeslip and normal faults in the Walker Lane zone within a single uniform regional stress tensor, this model requires that the discontinuous strike-slip faults be substantially weaker than the main Sierran frontal fault system.

Our slip data, including crosscutting striae on the same fault planes, support previous results from Owens Valley [Zoback, 1989] that indicate deformation within temporally distinct extensional and strike-slip stress regimes with a roughly constant WNW trending $\sigma_{3}$ axis. A recent change from a normal faulting to a strike-slip faulting stress regime is indicated by the crosscutting striae on faults in rocks $<300,000$ years old and is consistent with the dominantly strike-slip earthquake focal mechanisms and the youngest striae observed on faults in Plio-Quaternary deposits. Geologic control on the timing of the change is too poor to determine if there has been a single recent absolute change or if there is an alternating or cyclic variation in stress magnitudes.

A change from a normal faulting stress regime with $R \approx$ 0.75 to a strike-slip faulting stress regime with an $R \approx 0.1$ 0.2 , both with a WNW trending $\sigma_{3}$ axis, can be explained by an increase in $\sigma_{\text {NNE magnitude. Assuming that stress }}$ differences in the crust are predicted by the "frictional strength of optimally-oriented faults" model [Jaeger and Cook, 1979, p. 90] and using Byerlee's Law [Byerlee, 1978] and hydrostatic pore pressure, the primary difference between the inferred normal faulting regime and the strike-slip regime is an $\sim 80$ MPa difference in the magnitude of the effective maximum horizontal stress $\left(\sigma_{\mathrm{NNE}^{-}} P\right.$ ) for hydrostatic pore pressure. This value is far greater than typical earthquake stress drops, suggesting that the changes in stress regime are related to something other than the simple stress changes related to individual earthquake cycles (or alternately, that stress differences at focal depths may be smaller than predicted by frictional faulting theory, perhaps as a result of elevated pore pressure). The location of the WLZ between the deep-seated regional extension of the Basin and Range and the rightlateral strike-slip regional tectonics of the western plate boundary (presently the San Andreas fault) is no doubt responsible both for the Plio-Quaternary tectonic regimes as well as much of the late Tertiary and Mesozoic deformational history of strike-slip faulting acting in this zone. The historic (possibly extending back through the Holocene) strike-slip deformation in the WLZ may be in response to the development of a NNW trending zone of shear which may be accommodating roughly $20 \%$ of Pacific-North American plate motion [Dokka and Travis, 1990b].

\section{Appendix: Detailed Description of Important Fault Slip Localities}

\section{Dry Valley (Sites 4 and 5)}

Sites 4 and 5 are located along the western and eastern border faults, respectively, of the Dry Valley graben. The data 
were collected both on minor slickensides (centimeter to meter scale) within the fault zones and on the main border fault planes. All the sampled fault planes cut late Miocene-Pliocene (17-6 Ma) basalt flows. The morphology of the western fault scarp yields no indication of recent fault movement, whereas the eastern fault scarp is exposed along a steep free face in basalts and colluvium which probably indicates recent (Holocene) vertical fault displacement. Measurements for site 4 were made along a $3-\mathrm{km}$ segment of the east dipping range front scarp located 5 to $8 \mathrm{~km}$ NNW of the Double Check Well near Flanigan. Site 5 represents two localities along the west dipping range front fault zone adjacent to Dry Slick Hill and Mission Peak (which are $<1 \mathrm{~km}$ apart); both localities are $\sim 10 \mathrm{~km}$ north of the Double Check Well.

\section{Winnemuca (Site 11)}

Site 11 consists of three measurement localities on or close to the west dipping Nightingale range front fault escarpment which forms the eastern edge of the Winnemuca valley. All three localities are in canyons along a 5-km stretch of the fault (from $\sim 2 \mathrm{~km}$ north of the water tank of the "MGL mine" to 3 $\mathrm{km}$ south of this water tank). The measured striae represent deformation on minor planes within the fault zone proper which affect Plio-Pleistocene fanglomerates and Late Mesozoic quartzites, rather than on the actual major fault plane.

\section{Genoa Fault Zone (Sites 17 to 20 )}

Sites 17 to 20 are located on or close to the east dipping Genoa range front escarpment of the Sierran frontal fault zone which forms the western margin of Jack Valley. This Sierran frontal fault zone has a mean direction which trends N-S at sites 18 to 20, while at site 17 the frontal fault trends NNE.

Site 17 consists of several measurement localities of fault planes affecting Cretaceous granitic rocks along highwaỹ 50 , $2-3 \mathrm{~km}$ west of highway 395 . One locality was in road cuts just north of the gauging station at Clear Creek, and the second was along natural exposures along the banks of Clear Creek. Site 18 also consists of several measurement localities in Cretaceous granites in small canyons between Bennett and James Canyons, close to Jack Ranch.

Sites 19 and 20 record measurements along the main Genoa range front fault zone and represent two different kinds of fault slip data. Site 19 is along the prominent main bedrock escarpment exposed just west of state highway $206, \sim 1 \mathrm{~km}$ south of the town of Genoa (this site is shown in Figure 8). In contrast, site 20 represents stiae measurements on minor normal fault planes adjacent to the main range front fault which affects Cretaceaous granitic rocks and are exposed in road cuts of highway 206, 2 to $3 \mathrm{~km}$ south of Genoa.

\section{Antelope Valley (Site 21)}

Site 21 measurements were made on the east dipping range front escarpment forming the west margin of the Antelope Valley graben; this fault zone is part of the Sierran frontal fault zone. Striae data were collected south of Coleville, behind the Meadowcliff Motel, from both minor slickensides along the range front fault scarp and on major fault planes generally oblique to the frontal fault zone. The striae data were measured on inherited fractures which affect Cretaceaous granites and granodiorites.

\section{Smith Valley (Sites 25 and 26)}

Sites 25 and 26 are located in Smith Valley along state highway 208, where the road crosses low hills $\sim 4$ to $6 \mathrm{~km}$ east of the Smith Valley airport. Minor normal fault zones (1 to 2 $\mathrm{m}$ displacements) affecting Plio-Pleistocene fluvio-lacustrine deposits are exposed in road cuts as illustrated in Figure 10.

\section{Wassuk Fault Zone (Sites 30 to 34 )}

Sites 30 to 34 are located just east of U.S. highway 95, along the east dipping Wassuk range frontal fault zone. The striae measurements represent deformation on small planes within the fault zone proper (sites 30 to 33 ) and on the actual main bedrock fault plane (sites 33 and 34). Site 30 is $\sim 5 \mathrm{~km}$ north of Reese River Canyon; site 31 is between Penroc and Deadman Canyons; site 32 is $3 \mathrm{~km}$ south of Deadman Canyon; site 33 is between Cooper Canyon and Dry Creek; and site 34 is along the main escarpment just north of Cottonwood Creek.

\section{Pleasant Valley Fault Zone (Sites plv1-5)}

Sites plv1 to plv5 are located along the central segment of the west dipping Pleasant Valley fault scarp formed in 1915, specifically along the central part of the $30-\mathrm{km}$ long Pearce scarp segment [see Wallace, 1984b]. Sites plv1 to plv5 are located from north to south where bedrock is exposed in the scarp face; plv1 is at the latitude of the old Siard Ranch damaged in 1915; plv2 is $4 \mathrm{~km}$ north of Pearce Ranch; plv3 is just south of Golconda canyon; and plv4 and plv5 are located $\sim 8$ to $10 \mathrm{~km}$ south of Pearce Ranch. Data from plv1 and 2 were collected on minor (centimeter to meter scale) and major (more than $1 \mathrm{~m}$ scale) fault planes. Data from plv3 and plv5 represent deformation on small planes within the fault zone proper, while plv4 data represent major slickensides along a major quartzite escarpment.

\section{Dixie Valley Fault Zone (Sites dv1-3)}

Sites $d v 1$ to $d v 3$ are located along the central part of the east dipping Dixie Valley fault scarp formed in 1954 which forms the eastern border of the Stillwater range, west of Dixie Valley road. Site localities from south to north are: in the vicinity of Sheep and Coyote Canyons (dv1), between Little Box and Brush Canyons (dv2), and between Cottonwood and Hare Canyons (dv3). The data were collected on minor and major slickensides which represent deformation just adjacent to the fault front and along the major escarpment. The measured fault planes, at localities $d v 1$ and $d v 2$, affect Oligocene to early Miocene granites and granitic and metamorphic rocks with undifferentiated ages ranging between Jurassic and Miocene. At site dv3, they affect Mio-Pliocene and early Pleistocene(?) volcanic rocks.

\section{Olinghouse Fault Zone (Site Oling)}

This site is located along the range front fault, $\sim 2-3 \mathrm{~km}$ north of the "powerhouse" and gauging station near the Patrick interchange on Interstate 80, 26-28 km ENE of Reno. The slip measurements were made on major and minor 
slickensides along a major basaltic escarpment within the south dipping segment of the Olinghouse fault scarp formed in 1869.

\section{Rainbow Mountain Fault Zone (Site rm)}

This site consists of several data localities along the Rainbow Mountain fault scarp formed in 1954, between 5 and $10 \mathrm{~km}$ north of the U.S. highway 50 and just NNE of Salt Wells. Measurements were made on minor fault planes affecting both rhyolitic and basaltic Miocene flows.

\section{Owens Valley Fault Zone (Sites owens 1-2)}

The Owens Valley sites are all located along the northern segment of the Owens Valley fault zone (Figure 4c). At site owens 1 ( $\sim 2 \mathrm{~km}$ SSE of Big Pine) we observed only normal slip on minor faults cutting the main east dipping major fault scarp. Site owens 2, located about $6 \mathrm{~km} \mathrm{SSE} \mathrm{of} \mathrm{Big} \mathrm{Pine,} \mathrm{is} \mathrm{the}$ more important locality because it exposed crosscutting relationships between an older normal striae set and a younger strike-slip set. The majority of the data came from an en echelon, left-stepping east dipping scarp. However, the crosscutting relationships were observed along a roughly $1-\mathrm{m}$ high and 8-m wide west dipping fault scarp within this leftstepping en echelon scarp system (Figure 4).

Acknowledgments. This work was part of the Cooperative Research Program between the U. S. Geological Survey (USGS) and the URA CNRS Géophysique et Géodynamique Interne. O.B.'s participation was made possible in part by a CNES (Centre National d'Etudes Spatiales) grant. Special thanks are due to J. H. Stewart, R. F. Hardyman, M. M. Clark, and D. P. Schwartz, who provided maps and expertise on active faulting in the Walker Lane zone. We thank G. King for helpful discussions concerning the stress state changes in the Basin and Range province and Mark Zoback, Jack Stewart, and Michel Sébrier for helpful reviews which clarified our interpretations. We also thank $\mathrm{E}$. Carey-Gailhardis for modifying the orginal Carey stress inversion program to accommodate fixed inversions and $\mathrm{G}$. Roche for drafting of some of the figures.

\section{References}

Anderson, R.E., M.L. Zoback, and G. Thompson, Implications of selected subsurface data on the structural form and evolution of some basins in the northern Basin and Range Province, Nevada and Utah, Geol. Soc. Am. Bull., 94, 1055-1072, 1983.

Angelier, J., Neotectonique de l'Arc Egeen, Publ. 3, 417 pp., Soc. Geologique du Nord Publication, Villeneuve D'Ascq, France, 1979.

Angelier, J., Tectonic analysis of fault slip data sets, J. Geophys. Res., 89, 5835-5848, 1984.

Axelrod, D.I., Potassium-argon ages of some western Tertiary floras, Am. J. Sci., 264, 497-506, 1966.

Beanland, S., and M. M. Clark, The Owens Valley fault zone, and surface rupture associated with the 1872 earthquake, (abstract), Seismol. Res. Lett., 58, 32, 1987.

Beanland, S. and M. M. Clark, The Owens Valley fault zone, eastern California, and surface rupture associated with the 1872 earthquake, U. S. Geol. Surv. Bull. 1982, in press, 1995

Beck, M. E., Jr., On the mechanism of tectonic transport of oblique subduction, Tectonophysics, 93, 1-11, 1983.

Beck, M. E., Jr., C. Rojas, and J. Cembrano, On the nature of buttressing in margin-parallel strike-slip fault systems, Geology, 21, 755758, 1993.

Bell, J.W., Quaternary fault map of the Reno 1 by 2 degree quadrangle, scale $1: 250,000, U$. S. Geol. Surv. Open File Report, 81-982, 62 pp., 1981.

Bell, J.W., Quaternary fault map of Nevada, Reno sheet, scale 1:250,000, Map 79, Nev. Bur. Mines and Geol., Reno, 1984a.

Bell, J.W., Holocene faulting in western Nevada and recurrence of large-magnitude earthquakes, in 1984 Annual Meeting. Western Geological Excursions, vol. 4, pp. 388-402, Geological Society of America, Boulder, Colo., 1984b.

Bell, J. W., and T. Katzer, Timing of late Quaternary faulting in the 1954 Dixie Valley earthquake area, central Nevada, Geology, 18, 622-625, 1990.

Bell, J. W., D. B. Slemmons and R. E. Wallace, Roadlog: Reno to Dixie Valley-Fairview Peak earthquake areas, field trip 18, in 1984 Annual Meeting, Western Geological Excursions, vol. 4, pp. 425-72, Geological Society of America, Boulder, Colo., 1984.

Bellier, O., and M. L. Zoback, Late Cenozoic state of stress changes along the Walker Lane Zone (Basin and Range - USA), Ann. Geophysicae, 9, C37, 1991.

Bellier, O., J.F. Dumont, M. Sébrier, and J.L. Mercier, Geological constraints on the kinematics and fault-plane solution of the Quiches fault zone: reactivated during the 10 November 1946 Ancash earthquake, Northern Peru, Bull. Seismol. Soc. Am., 81(2), 468-490, 1991.

Bird, P., and R. W. Rosenstock, Kinematics of present crust and mantle flow in southern California, Geol. Soc. Am. Bull., 95, 945957, 1984.

Bonham, H. F., Geology and mineral deposits of Washoe and Storey Counties, Nevada, Nev. Bur. Mines Geol. Bull. 70, 139 pp., 1969.

Bonham, H. F., and D. K. Rogers, Mt. Rose NE Quadrangle, geologic map, scale 1:24,000, Map 4B-g, Nev. Bur. Mines Geol., Reno, 1983.

Bonilla, M. G., R. K. Mark and J. J. Lienkaemper, Statistical relations among earthquake magnitude, surface rupture length, and surface fault displacement, Bull. Seis. Soc. Am., 74, 2379-2422, 1984.

Bott, M. H. P., The mechanism of oblique slip faulting, Geol. Mag., 96, 109-117, 1959.

Byerlee, J. D., Friction of rocks, Pure Appl. Geophys., 116, 615-626, 1978.

Carey, E., Recherche des directions principales de contraintes associées au jeu d'une population de failles, Rev. Géol. Dyn. Géogr. Phys., 21, 57-66, 1979.

Carey, E. and B. Brunier, Analyse théorique et numérique d'un modèle mécanique élémentaire appliqué à l'étude d'une population de failles, C.R. Acad. Sci. Paris, Sér. D.. 279, 891-894, 1974.

Clark, M. M., J.C. Yount, P.R. Vaughan and R.L. Zepeda, Map showing surface rupturse associated with the Mammoth Lakes, California, earthquakes of May 1980, scale 1:24,000, U.S. Geol. Surv. Misc. Field Stud. Map MF-1396, 1982.

Clark, M. M., et al., Preliminary slip-rate table and map of late-Quaternary faults of California, U.S. Geol. Surv. Open-File Rep., 84-106, 12 pp., 1984.

Cockerham, R. S., and E. J. Corbett, The July 1986 Chalfant Valley, California, earthquake sequence: Preliminary results, Bull. Seis. Soc. Am., 77, 280-289, 1987.

dePolo, C. M., and A. R. Ramelli, Preliminary report on surface fractures along the White Mountains fault zone associated with the July 1986 Chalfant Valley earthquake sequence, Bull. Seis. Soc. Am., 77, 290-296, 1987.

dePolo, C.M., J.W. Bell, and A.R. Ramelli, Geometry of strike-slip faulting related to the 1932 Cedar Mountain earthquake, central Nevada, Geol. Soc. Am. Abstr. Programs, 19, 371, 1987.

dePolo, C. M., D. G. Clark, and D. B. 
Slemmons, Historical Basin and Range Province surface faulting and fault segmentation, U.S. Geol. Surv Open File Rep., 89-315, 131-162, 1989.

dePolo, C. M., D. G. Clark, D. B. Slemmons and A. R. Ramelli, Historical surface faulting in the Basin and Range Province, western North America: Implications for fault segmentation, J. Struct Geol., 13(2), 123136, 1991.

Dokka, R. K., and C. J. Travis, Late Cenozoic strike-slip faulting in the Mojave Desert, California, Tectonics, 9, 311-340, 1990a

Dokka, R. K., and C. J. Travis, Role of the eastern California shear zone in accommodating Pacific-North American plate motion, Geophys. Res. Lett., 17, 13231326, 1990b.

Doser, D. I., Earthquake processes in the Rainbow Mountain, Fairview Peak-Dixie Valley, Nevada, region, 1954-1959, J. Geophys. Res., 91, 12,572-12,586, 1986.

Doser, D. I., Source Parameters of earthquakes in the Nevada Seismic Zone, 1915-1943, J. of Geophys. Res., 93, 15,001-15,015, 1988.

Eaton, G. P., Regional geophysics, Cenozoic tectonics, and geologic resources of the Basin and Range province and adjoining regions, in 1979 Basin and Range Symposium, edited by G.W. Newman and H.D. Goode, pp. 11-39, Rocky Mountain Asso. of Geol.., Denver, Colo., 1979.

Eaton, G. P., R. R. Wahl, H. J. Prostka, D. R. Mabey and M. D. Kleinkopf, Regional gravity and tectonic patterns: Their relation to Cenozoic epeirogeny and lateral spreading in the western Cordillera, Mem. Geol. Soc. Am. , 152, 51-91, 1978.

Everden, F., and G. T. James, Potassium-argon dates and the Tertiary floras of North America, Am. J. Sci., 264, 945-974, 1964.

Fitch, T. J., Plate convergence, transcurrent faults, and internal deformation adjacent to Southwest Asia and the western Pacific, $J$. Geophys. Res., 77, 4432-4461, 1972.

Gianella, V.P., Earthquake and faulting, Fort Sage Mountains, California, December, 1950, Bull. Seismol. Soc. Am., 47, 173-177, 1957.

Gianella, V.P. and E. Callaghan, The earthquake of December 20, 1932, at Cedar Mountain, Nevada, and its bearing on the genesis of Basin Range structure, J. Geol., 42, 1-12, 1934.

Gillespie, A.R., Quaternary glaciation and tectonics in the south-eastern Sierra Nevada, Inyo County, California, Ph.D. thesis, 695 pp., Calif. Inst. of Technol., Pasadena, 1982.

Gross, W. K., and J. C. Savage, Deformation associated with the 1986 Chalfant Valley earthquake, eastern California, Bull. Seismol. Soc. Am., 77, 306-310, 1987.

Hardyman, R. F., Strike-slip, normal, and detachment faults in the northern Gillis Range, Walker Lane of west-central
Nevada, Geol. Soc. Am., in 1984 Annual Meeting, Western Geological Excursions, vol. 4, pp. 184-199, Geological Sociey of America, Boulder, Colo., 1984.

Hill, D. P., R. A. Bailey and A. S. Ryall, Active tectonic and magmatic processes beneath Long Valley Caldera, eastem California: An Overview, J. Geophys. Res., 90, 11,111$11,120,1985$.

Jaeger, J. C., and N. G. W. Cook, Fundamentals of Rock Mechanics, 3rd ed., 593 pp., Chapman and Hall, London, 1979.

Jarrard, R.D., Terrane motion by strike-slip faulting of fore-arc slivers, Geology, 14, 780-783, 1986.

Lide C. S., and A. S. Ryall, Relationship between aftershock locations and mechanisms of the May 1980 Mammoth Lakes earthquakes, J. Geophys. Res., 90 , 11,151-11,154, 1985.

Lienkaemper, J. J., S. K. Pezzopane, M. M. Clark and M. J. Rymer, Fault fractures formed in association with the 1986 Chalfant Valley, California, earthquake sequence: Preliminary report, Bull. Seismol. Soc. Am., 77, 297-305, 1987.

Lubetkin, L. K. C., and M. M. Clark, Late Quatemary activity along the Lone Pine fault, eastern California, Geol. Soc. Am Bull., 100, 755-766, 1988

Luedke, R. G., and R. L. Smith, Map showing distribution, composition, and age of late Cenozoic volcanic centers in California and Nevada, U. S. Geol. Surv. Misc. Invest. Map, I-I09IC, 1981.

Lydon, P. A., T. E. Gay, Jr., and C. W. Jennings, Geologic map of California: Westwood sheet, scale 1:250,000, Div. of Mines and Geol., Sacramento, Calif., 1960.

Matthews, R. A. and J. L. Burnett, Geologic map of California: Fresno sheet, scale 1:250,000, Div. of Mines and Geol., Sacramento, Calif., 1965.

McCaffrey R., Slip-vectors and stretching of the Sumatra fore-arc, Geology, 19, 881-884, 1991.

Mercier, J.L., M. Sébrier, A. Lavenu, J. Cabrera, O. Bellier, D. Bonnot, J.F. Dumont, D. Huaman, and J. Macharé, Changes in stress pattern above a subduction zone of Andean type: The Andes of Peru and Bolivia during the Pliocene-Pleistocene, $J$. Geophys. Res. 97, 11,945-11,982, 1992.

Molinari, M. P., Late Cenozoic structural geology of Stewart and Monte Cristo Valleys, Walker Lane of west central Nevada, in 1984 Annual Meeting, Western Geological Excursions, vol. 4, pp. 219-231, Geological Society of America, Boulder, Colo., 1984.

Moos, D., and M.D. Zoback, State of stress in the Long Valley caldera, California, Geology, 21, 837-840, 1993.

Mount, V.S., and J. Suppe, State of stress near the San Andreas fault: Implication for wrench tectonics, Geology, 15, 1143-1146, 1987.

Mount, V.S., and J. Suppe, Present-day stress orientations adjacent to active strike-slip faults: California and Sumatra, J. Geophys. Res., 97, 11,995-12,013, 1992.

Noble, D. C., Mesozoic geology of the southern Pine Nut Range, Douglas County, Nevada Ph.D. thesis, 200 pp., Stanford Univ., Stanford, Calif., 1962.

Oppenheimer, D.H., P. A. Reasenberg, and R. W. Simpson, Fault plane solution for the 1984 Morgan Hill, California, earthquake sequence: Evidence for the state of stress on the Calaveras fault, J. Geophys. Res., 93. 9007-9026, 1988.

Page, B. M., Preliminary geologic map of a part of the Stillwater Range, Churchill County, Map 28, Nev. Bur. of Mines and Geol., Reno, 1965.

Pease, R. C., Genoa Quadrangle, geologic map, scale 1:24,000, Map IC-g, Nev. Bur. of Mines and Geol., Reno, 1980.

Proffett, J. M., Jr., Cenozoic geology of the Yerington District, Nevada, and implications for the nature and origin of Basin and Range faulting, Geol. Soc. Am. Bull., 88, 247-266, 1977.

Proffett, J. M., and B. H. Proffett, Stratigraphy of the Tertiary ash-flow tuffs in the Yerington district, Nevada, Rep. 27, 28 pp., Nev. Bur. of Mines and Geol., Reno, 1976.

Ritz, J.F., and A. Taboada, Revolution stress ellipsoids in brittle tectonics resulting from an uncritical use of inverse methods, Bull. Soc. Géol. Fr., 164(4), 519-531, 1993.

Romney, C., The Dixie Valley-Fairview Peak, Nevada earthquakes of December 16, 1954, seismic waves, Bull. Seismol. Soc. Am., 47, 301-320, 1957

Ryall, A., and K. Priestley, Seismicity, secular strain and maximum magnitude in the Excelsior Mountains area, Nevada and eastern California, Geol Soc. Am. Bull., 86, 1585-1592, 1975.

Ryall, A., and F. Ryall, Spatial-temporal variations in seismicity preceding the May, 1980, Mammoth Lakes, California, earthquakes, Bull. Seismol. Soc. Am., 71, 2739, $1981 \mathrm{a}$.

Ryall F., and A. Ryall, Attenuation of $P$ and $S$ waves in a magma chamber in Long Valley caldera, California, Geophys. Res. Lett., 8 , 557-560, $1981 b$.

Ryall, A., D. B. Slemmons, and L. D. Gedney, Seismicity, tectonism, and surface faulting in the western United States during historic time, Bull. Seismol. Soc. Am., 56, 1105-1135, 1966.

Sanders, C.O. and D.B. Slemmons, Recent crustal movements in the central Sierra Nevada-Walker Lane region of CaliforniaNevada, III, The Olinghouse fault zone, Tectonophysics, 52, 585-597, 1979.

Sauber, J., W. Thatcher and S.C. Solomon, Geodetic measurements of deformation in 
the central Mojave Desert, California, $J$. Geophys. Res., 91, 12,683-12,693, 1986.

Savage, J.C., M. Lisowski, and W.H. Prescott, An apparent shear zone trending northnorthwest across the Mojave Desert into Owens Valley, eastern California, Geophys. Res. Lett., 17, 2113-2116, 1990

Sébrier, M., J.L. Mercier, J. Macharé, D. Bonnot, J. Cabrera, and J.L. Blanc, The state of stress in an overriding plate situated above a flat slab: The Andes of central Peru, Tectonics, 7(4), 895-928, 1988.

Silberman, M. L., and E. H. McKee, Ages of Tertiary volcanic rocks and hydrothermal precious metal deposits in central and western Nevada, Rep. 19, pp. 67-72, Nev. Bur. of Mines and Geol., Reno, 1974.

Slemmons, D. B., Geological effects of the Dixie Valley-Fairview Peak, Nevada, earthquakes of December 16, 1954, Bull. Seismol. Soc. Am., 47, 353-375, 1957.

Slemmons, D. B., State of the art for assessing earthquake hazards in the United States, in Faults and Earthquake Magnitude, Misc. Pap. S-73-1, Rep. 6, 166 pp., U.S. Army Eng. Waterways Exp. Stn., Vicksburg, Miss., 1977.

Slemmons, D. B., K. V. Steinbrugge, D. Tocher, G. B. Oakeshott and V. P. Gianella, Wonder, Nevada, earthquake of 1903, Bull. Seismol. Soc. Am., 49, 251-265, 1959.

Slemmons, D. B., A. E. Jones and I. I. Gimlett, Catalog of Nevada earthquakes, 1852-1960, Bull. Seismol. Soc. Am., 55, 519-566, 1965.

Slemmons, D. B., D. Van Wormer, E. I. Bell, and M. L. Silberman, Recent crustal movements in the Sierra Nevada-Walker Lane region of California-Nevada, I, Rate and style of deformation, Tectonophysics, 2 , 561-570, 1979.

Stewart, J. H., Basin-range structure in western North America: A review, Mem. Geol. Soc. Am., 152, 1-31, 1978.

Stewart, J. H., Regional tilt patterns of Late Cenozoic basin-range fault blocks, western United States, Geol. Soc. Am. Bull.. 91, 460464,1979

Stewart, J. H, Cenozoic structure and tectonics of the northern Basin and Range province, California, Nevada, and Utah, Spec. Rep., 13, pp. 25-39, Geotherm. Resour. Counc., Davis, Calif., 1983.

Stewart, J. H., Tectonics of the Walker Lane belt, western Great Basin-Mesozoic and Cenozoic deformation in a zone of shear, in Metamorphism and Crustal Evolution of the Western United States, Rubey vol. VII, pp. 683-713, Prentice-Hall, Englewood Cliffs, N. J., 1988.

Stewart, J. H., Walker Lane belt, Nevada and California - An overview, in Special Pub., Walker Lane Symposium: Structure, Tectonics and Mineralization of the Walker Lane, pp. 1-16, Geol. Soc. of Nevada, Reno, Nevada, 1992.

Stewart, J. H., and J. E. Carlson, Geologic map of north-central Nevada, Map 50, Nev. Bur. of Mines and Geol., Reno, 1976a.

Stewart J. H., and J. E. Carlson, Cenozoic rocks of Nevada - Four maps and brief description of distribution, lithology, age, and centers of volcanism, Map 52, Nev. Bur. of Mines and Geol., Reno, 1976b.

Stewart, J. H. and J. E. Carlson, Geologic map of Nevada, scale $1 \cdot 500,000$, U.S. Geol. Surv., Reston, Va., 1978.

Stewart, J. H., and J. C. Dohrenwend, Geological map of the Wellington Quadrangle, Nevada, scale 1:50,000, U.S. Geol. Surv. Open-File Rep., 84-211, 10 pp., 1984.

Stewart, J. H., J. E. Carlson, and D. C. Johannesen, Geologic map of the Walker Lake $1^{\circ}$ by $2^{\circ}$ quadrangle, California and Nevada, scale 1:250,000, U.S. Geol. Survey Misc. Field Stud. Map MF-1382-A, 1982.

Stock, J. M., J. Healy, and J. Svitek, Hydraulic fracturing stress measurements at Yucca Mountain, Nevada, and relationship to the regional stress field, J. Geophys. Res., 90 , 8691-8706, 1985.

Strand, R. G., Geologic map of California: Mariposa sheet, scale 1:250,000, Calif. Div. of Mines and Geol., Sacramento, Calif., 1967.

Thatcher, W., and T. C. Hanks, Source parameters of southern California earthquakes, J. Geophys. Res., 78, 85478576, 1973.

Thompson, G. A., and D. B. Burke, Rate and direction of spreading in Dixie Valley, Basin and Range province, Nevada, Geol. Soc. Am. Bull., 84, 627-632, 1973.

Tsai, Y. B., and K. Akı, Source mechanism of the Truckee California earthquake of September 12, 1966, Bull. Setsmol. Soc. Am., 60, 1199-1208, 1970

Turrin, B. D., and A. Gillespie, K/Ar ages of basaltic volcanism of the Big Pine volcanic field, California: Implicaitons for glacial stratigraphy and neotectonics of the Sierra Nevada, Geol. Soc. Am. Abstr. Programs, 18, 777, 1986.

Vergely, P., W. Sassi, and E. Carey-Gailhardis, Analyse graphique des failles à l'aide de focalisations de stries, Bull. Soc. Géol. Fr., 2, 395-402, 1987.

Vetter, U. R., Variation of the regional stress tensor at the Western Great Basin boundary from the inversion of earthquake focal mechanisms, Tectonics, 9, 63-79, 1990.

Vetter, U. R., and A. S. Ryall, Systematic change of focal mechanisms with depth in western Great Basin, J. Geophys. Res., 88, 8237-8250, 1983.

Vikre, P. G., and E. H. McKee, New K-Ar ages of hydrothermal minerals and igneous rocks from the westem Virginia Range, Washoe and Storey Counties, Nevada, Isochron/West, 48, 11-15, 1987.

Wallace, R. E., Map of young fault scarps related to earthquakes in north-central
Nevada, U.S. Geol. Surv. Open File Rep., 79-1554, 1979.

Wallace, R. E., Patterns and timing of late Quaternary faulting in the Great Basin Province and relation to some regional tectonic features, J. Geophys. Res., 89, 5763-5769, 1984a.

Wallace, R. E., Fault scarps formed during the earthquakes of October 2, 1915, Pleasant Valley, Nevada and some tectonic implications, U.S. Geol. Surv. Prof. Pap. 1274A, 33 pp., 1984b.

Wallace, R. E., Grouping and migration of surface faulting and variation in slip rate on faults in the Great Basin Province, Bull. Seismol. Soc. Am., 77, 868-876, 1987.

Ward S. N., Pacific-North America plate motions: New results from very long baseline interferometry, J. Geophys. Res., 95, 21,965-21,981, 1990.

Watson, G. S., More significance tests on the sphere, Biometrika, 47, 87-91, 1960.

Wesnousky, S. G., and C. H. Jones, Oblique slip, slip partitioning, spatial and temporal changes in the regional stress field, and the relative strength of active faults in the Basin and Range, western United States, Geology, 22, 1031-1034, 1994

Whitebread, D. H., Alteration and geochemistry of Tertiary volcanic rocks in parts of the Virginia City quadrangle, Nevada, U.S. Geol. Surv. Prof. Pap. 936, 43 pp., 1976.

Wright, L. A., Late Cenozoic fault patterns and stress field in the Great Basin and western displacement of the Sierra Nevada block, Geology. 4, 489-494, 1976.

Zoback, M. D., et al., New evidence on the state of stress of the San Andreas fault system, Science, 238, 1105-1111, 1987.

Zoback, M. L., State of stress and modern deformation of the Northern Basin and Range province, J. Geophys. Res., 94, 7105 $7128,1989$.

Zoback, M. L., Stress field constraints on intraplate seismicity in eastern North America, J. Geophys. Res., 97, 11,761$11,782,1992$.

Zoback, M.L., and S. Beanland, Temporal variations in stress magnitude and style of faulting along the Sierran frontal fault system, Geol. Soc. Am. Abstr. Programs, 18, 801, 1986.

Zoback, M. L., and G. A. Thompson, Basin and Range rifting in northern Nevada - clues from a mid-Miocene rift and its subsequent offset, Geology, 6, 111-116, 1978.

Zoback, M. L., and M. D. Zoback, State of stress in the conterminous United States, $J$. Geophys. Res., 85, 6113-6156, 1980.

Zoback, M. L., and M. D. Zoback, Tectonic stress field of the conterminous United States, Mem. Geol. Soc. Am., 172, 523-539, 1989.

Zoback, M. L., R. E. Anderson and G. A. Thompson, Cenozoic evolution of the state 
of stress and style of tectonism of the Basin and Range province of the western United States, Philos. Trans. R. Soc. London A, 300, 407-434, 1981.

O. Bellier, URA D1369, Centre National de la Recherche Scientifique,
Géophysique and Géodynamique Interne, Université de Paris-Sud, Bat. 509, Orsay Cedex 91405, France. (e-mail: bellier@geophy.lps.upsud.fr) Stop 977, 345 Middlefiedl Road, Menlo Park, CA 94025.

M. L. Zoback, U. S. Geological Survey,
Branch of Seismology, Mail (e-mail: zoback@ andreas.wr.usgs.gov)

(Received August 17, 1992; revised February 23, 1994; accepted March 2, 1994.) 